\title{
TOP2B: The First Thirty Years
}

\author{
Caroline A. Austin ${ }^{1, *}$, Ka C. Lee ${ }^{1}$, Rebecca L. Swan ${ }^{1}$, Mushtaq M. Khazeem ${ }^{1}$, \\ Catriona M. Manville ${ }^{1}$, Peter Cridland ${ }^{1}$, Achim Treumann ${ }^{2}{ }^{-0}$, Andrew Porter ${ }^{2}$, \\ Nick J. Morris ${ }^{3}$ and Ian G. Cowell ${ }^{1, *}$ \\ 1 Institute for Cell and Molecular Biosciences, Faculty of Medical Sciences, Newcastle University, \\ Newcastle upon Tyne NE2 4HH, UK; larrylee585@gmail.com (K.C.L.); r.bramley@ncl.ac.uk (R.L.S.); \\ M.M.K.Khazeem2@newcastle.ac.uk (M.M.K.); manville@rand.org (C.M.M.); peter.cridland@gmail.com (P.C.) \\ 2 NUPPA, Newcastle University, Newcastle upon Tyne NE2 4HH, UK; \\ achim.treumann@newcastle.ac.uk (A.T.); Andrew.Porter@newcastle.ac.uk (A.P.) \\ 3 School of Biomedical Sciences, Faculty of Medical Sciences, Newcastle University, \\ Newcastle upon Tyne NE2 4HH, UK; n.j.morris@ncl.ac.uk \\ * Correspondence: caroline.austin@ncl.ac.uk (C.A.A.); ian.cowell@ncl.ac.uk (I.G.C.)
}

Received: 18 June 2018; Accepted: 11 September 2018; Published: 14 September 2018

check for updates

\begin{abstract}
Type II DNA topoisomerases (EC 5.99.1.3) are enzymes that catalyse topological changes in DNA in an ATP dependent manner. Strand passage reactions involve passing one double stranded DNA duplex (transported helix) through a transient enzyme-bridged break in another (gated helix). This activity is required for a range of cellular processes including transcription. Vertebrates have two isoforms: topoisomerase II $\alpha$ and $\beta$. Topoisomerase II $\beta$ was first reported in 1987 . Here we review the research on DNA topoisomerase II $\beta$ over the 30 years since its discovery.
\end{abstract}

Keywords: Topoisomerase II; TOP2; Cell cycle; cell biology; transcription; review

\section{Discovery of DNA Topoisomerase II $\beta$ (TOP2B) Protein}

In 1987 the first report of a second type II isoform in mammalians was published by Fred Drake's group at Smith Kline French (SKF); this isoform was called DNA topoisomerase II $\beta$ (TOP2B) [1]. The purification of topoisomerase II $\beta$ was from a murine P388 leukemia cell line selected for resistance to amsacrine [2]. This amsacrine resistant cell line also displayed resistance to other drugs that targeted topoisomerase II, but not to camptothecin which targets topoisomerase I. When topoisomerase II was purified from the resistant cell line and the sensitive cell line, two different sized bands were seen on SDS-PAGE gels, one of $170 \mathrm{KDa}(\mathrm{p} 170)$ and the other $180 \mathrm{KDa}(\mathrm{p} 180)$, but the relative amounts were different in the sensitive and resistant cell lines. Partial proteolysis with Staphylococcus V8 protease revealed different cleavage products with p170 and p180, suggesting that they were different isoforms. Antibodies were raised to each of the two purified proteins and used on western blots of cell lysates prepared by boiling immediately in SDS. The antibodies recognised specifically p170 or p180, supporting the distinct identities of the two proteins and discounting the alternative explanation that the p170 was a proteolytic fragment of the p180 (one suggestion in the field at that time).

Interestingly, two other studies published at this time also provided evidence for a second type II isoform. Joseph Holden and his team were analysing levels of topoisomerase activity and found TOP2 activity in non-proliferating tissue, which was contrary to the previous idea that only proliferating cells contain type II topoisomerase activity; they suggested this was evidence that human tissues may contain more than one form of the enzyme [3]. Joaquim Roca and Cristobal Mezquita were analysing the role of topoisomerases in chromatin changes during spermatogenesis. The presence of type II DNA topoisomerase activity in both replicating chicken testis cells and in non-replicating chicken spermatids provided evidence that there may be a second isoform of topoisomerase II in non-replicating cells [4]. 


\section{Cloning the cDNA Encoding TOP2B}

Before whole genome sequencing, obtaining coding sequences was a very time consuming process. Three groups working independently reported the cloning of partial cDNAs encoding TOP2B, using various approaches. Fred Drake and K.B. Tan's team used a Drosophila Top2 to screen a cDNA library derived from human Raji-HN2 cells; they cloned two classes of cDNAs reported in Chung et al. [5]. One class was identical in sequence to part of the cDNA cloned for TOP2 by Monica Tsai-Pflugfelder et al. in 1988 [6]. The second class of cDNA shared 75\% nucleotide identity with the other class. These were partial clones (SP1 and SP11) for the two different isoforms: topoisomerase II $\alpha$ (TOP2A) and topoisomerase II $\beta$ (TOP2B); the region encoded by clone SP11 is shown in Figure 1.

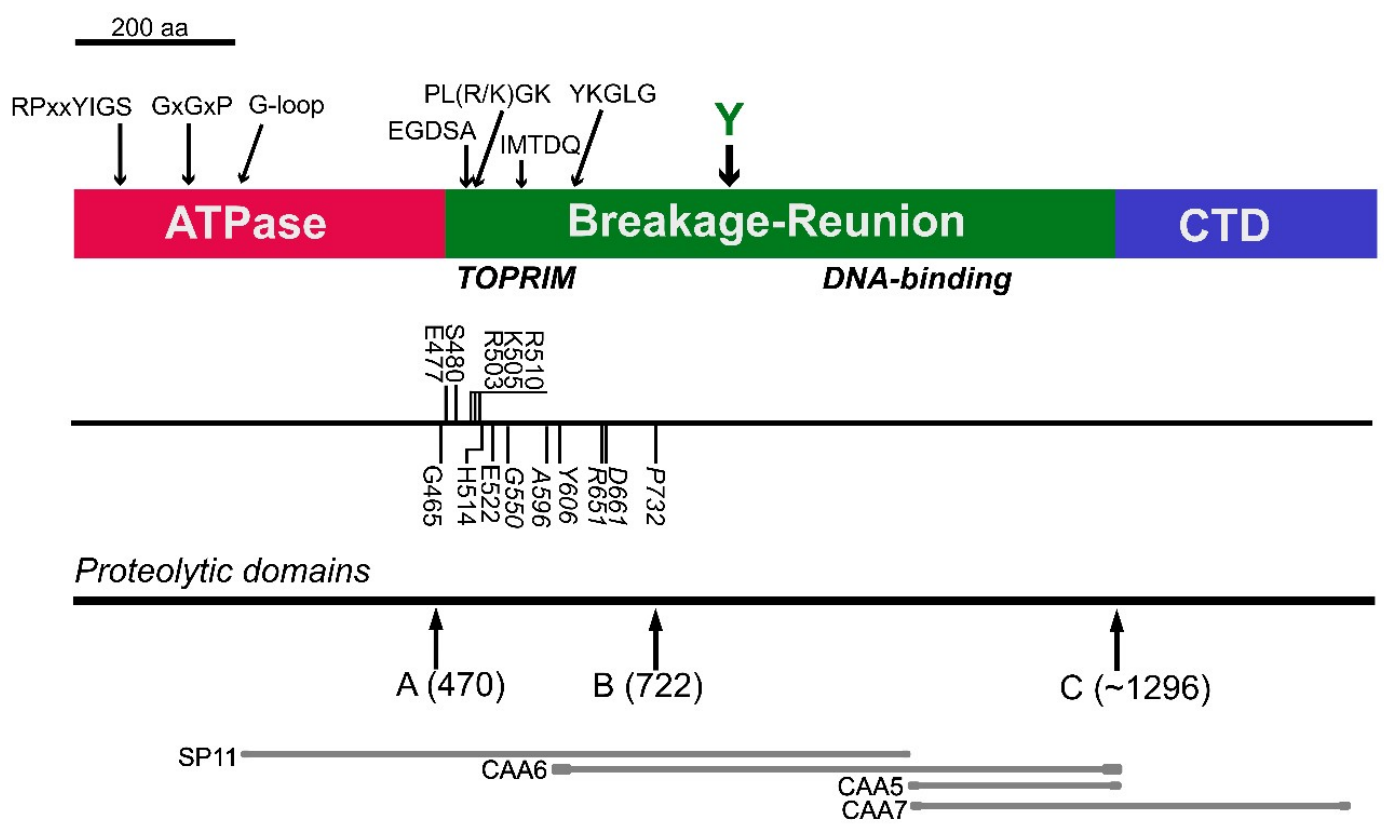

Figure 1. Schematic representation of the domain arrangement of human topoisomerase II $\beta$. The ATPase domain is shown in red, the breakage-reunion domain in green and the C-terminal domain in blue. The positions of conserved motifs are marked above. The line underneath shows the location of site-directed mutations reported by West et al. [7] (above) and mutations selected for drug resistance reported in Leontiou et al. [8] (below). The locations of inter-domain hinge regions elucidated by limited proteolysis reported in Austin et al. [9] are also shown. At the bottom of Figure 1, the locations of the initial partial cDNA clones encoding portions of TOP2B are shown [5]; SP11, and CAA5, clone CAA6, confirming that CAA5 and SP11 were part of the same gene, are also shown $[10,11]$.

In a parallel study, a novel topoisomerase II cDNA clone was identified adjacent to the region cloned by Chung et al. [10]. Two types of clone were identified, CAA4 and CAA5; CAA4 was identical to part of the TOP2A identified by Tsai-Pflugfelder et al., in 1988 from HeLa [6] cells and CAA5 was a novel cDNA, which shared $62 \%$ identity with TOP2A and aligned with the end of the SP11 clone reported by Chung et al. [5]. The region encoded by clone CAA5 is shown in Figure 1. These clones were isolated from a human HeLa cell lambda GT10 cDNA library by screening with a small, $231 \mathrm{bp}$ cDNA (CAA1) that had been isolated by expression screening using a polyclonal antisera raised to calf thymus topoisomerase II [12]. Further screening isolated larger clones (CAA6 and CAA7) that confirmed this novel cDNA was part of TOP2B. Clustal alignments of the sequences determined that TOP2A and TOP2B shared homology with topoisomerases from other species and that there were motifs conserved across all species. These conserved motifs are shown in Figure 1 [9,11]. Tsutsui et al., 1993 [13] isolated $T O P 2 B$ cDNA clones from rat by reverse transcriptase PCR using degenerate oligonucleotides encoding regions conserved between human and Drosophila topoisomerase II. The full coding sequence for TOP2B was also reported by Jenkins et al., 1992 [14], using a size selected cDNA library screened by 
hybridisation using a PCR product generated with primers whose sequences were derived from the previously published partial clones. The chromosomal mapping revealed human topoisomerase II $\alpha$ (TOP2A) is located on chromosome $17[6,15]$ and human topoisomerase II $\beta$ (TOP2B) on chromosome $3[14,15]$. These studies confirmed that TOP2B is a new isoform, not a splice variant, of TOP $2 A$. The TOP $2 B$ gene was subsequently cloned and confirmed TOP $2 B$ was a paralog of TOP $2 A$ having arisen by gene duplication of TOP2A [16,17]. A splice variant of TOP2B was reported by Davies et al., in 1993 [18]. There have been several studies on TOP2B gene regulation; the TOP2B promoter lacks a canonical TATA box $[19,20]$. Promoter activity is regulated by nuclear factor-Y (NF-Y)- and specificity protein-1 (Sp1) [20]. TOP2B expression has also been reported to be regulated by Nurr1 [21]. TOP2A and TOP2B homologues have been identified in at least 97 species, including mice, chicken and zebrafish, and appears to be specific to vertebrates.

\section{Protein Characterisation}

TOP2A and TOP2B are paralogues that share significant sequence identity; they both have an $\mathrm{N}$ terminal ATPase domain, a central breakage and re-joining domain and a C-terminal domain. Limited proteolysis revealed the accessible domain boundaries; the domains and the location of the proteolytic sites are indicated in Figure 1 [9]. The domain arrangement is conserved between all type II topoisomerases, from bacterial and phage enzymes through to human enzymes. TOP2B shares $68 \%$ identity at the amino acid level with TOP2A, but this is not spread evenly through the protein. The $\mathrm{N}$-terminal three quarters of the enzyme, bearing the ATPase domain and the central breakage re-joining domain, share $78 \%$ amino acid identity while the least conserved domain C-terminal domain shares only $34 \%$ amino acid identity. The divergent sequence of the C-terminal domain suggests it may play a role in the differential activities of the two isoforms both in vitro and in vivo. The domains are conserved from bacterial gyrase to human TOP2 [11]. Amino acid comparisons reveal a number of very conserved motifs, shown in Figure 1, and include RP-YIGS, G-G-P motif, the G-loop consisting of three conserved glycine's, EGDSA, PLRGK and IMTDQDQDG motifs, and YKGL and RY where $Y$ is the active site tyrosine [11]. Production of recombinant protein enabled studies where absolutely conserved residues were mutated. Mutation of residues E477, R503 and R505 caused loss of function in vivo, and mutation of E477 and K505 altered the magnesium optima in vitro. Residues D557, D559 and D561 are conserved in type I \& II topoisomerases, and comparisons with DNA polymerases suggested that they are involved in magnesium co-ordination [7]. A number of these conserved residues, E477 and G478 in EGDSA; G504 in PLRGK; D557, D558 and G562 in IMTDQDQDG are anchor residues in the TOPRIM domain conserved between type 1A and type II topoisomerases, DnaG-type primases, OLD family nucleases and RecR proteins [22]. The crystal structure of the TOP2B core including the TOPRIM domain has been reported [23], and the core of TOP2A has also been crystallised [24]. This domain of TOP2A and TOP2B displays structural similarity between the two isoforms and with the yeast TOP2 core [25]. The structure and mechanism have been extensively reviewed, see for example [25-27]. The ATPase domain of TOP2A has been crystallised [28], but not that of TOP2B. There is no structural data on either TOP2A or TOP2B C-terminal domains. The C-terminal domain has least homology between the isoforms and is the site for the nuclear localisation signals and many post translational modifications including phosphorylation, sumoylation, ubiquitination, acetylation [29]. Recombinant proteins have been used to determine in vitro activities, and in vitro both isoforms exhibit strand passage activity, evidenced by decatenation and relaxation assays. Constructs with the CTDs swapped between the isoforms were used to investigate the function of the CTD in vitro [30,31]. Truncated TOP2B lacking the CTD bound to DNA most strongly, suggesting the CTD may have a negative regulatory role on DNA binding. In cells the CTDs confer isoform specificity [32,33].

\section{Expression of TOP2B}

The availability of cDNA clones to TOP $2 B$ and TOP $2 A$ allowed various groups to visualise the RNA transcripts by northern blotting, and in situ hybridisation. Northern Blotting analysis of 
total RNA extracted from 22 tissues in 3-month-old mice showed that the thymus expressed the highest levels of both Top $2 a$ and Top $2 b$. For Top $2 a$ the spleen and bone marrow also showed high level expression. Testis and intestine expressed an intermediate level of Top $2 a$ and ovary, heart, breast and stomach showed low level expression. Top $2 a$ was not detectable in the other tissues studied. Top $2 b$ expression was detectable in 19 of the tissues analysed [34]. Northern blotting of RNA extracted from tissues of two-week-old rats also showed high levels of Top $2 a$ in spleen and thymus, but not in brain, lung, heart, liver, intestine or muscle. As seen in murine tissues, Top $2 b$ was also expressed more widely in rat tissues [13].

Top $2 a$ and Top $2 b$ expression was analysed in murine liver and brain before and after birth. Strikingly Top $2 b$ was induced more than 6 fold in the brains of newborn mice compared to embryos, but not in liver, suggesting an important role in neonatal brain [34]. Developing rat brain has also been analysed. Northern blotting on RNA extracted from rat brain showed high levels of Top $2 a$ in embryonic rat brain and in the cerebellum 2 days after birth, but Top2a levels were undetectable 4 weeks after birth. The pattern of expression suggested Top $2 a$ is only expressed in proliferating cells. In contrast, Top $2 b$ was present in the embryo and in the post-natal stages sampled (fetal 15 days \& 19 days; postnatal 2 days, 2, 4, 12 and 32 weeks). More detailed location of transcripts was determined by in situ hybridisation of rat brain sections from postnatal day 10. Top $2 a$ was only seen in the proliferating regions, whereas the signal for Top $2 b$ was much more widespread and very intense in the cerebellum. This is shown clearly in an in situ figure in Tsutsui et al., 1991 [13].

RNA in situ in human fetal tissues (kidney, brain, intestine, liver, lung and placenta) showed differential expression of TOP $2 A$ and TOP2B, with TOP $2 A$ expressed most strongly in zones of proliferation [35]. In situ hybridisation of foetal cortex showed TOP2B expressed through the cortex [36]. This study also analysed the protein expression in human foetal brain using immunohistochemistry; this showed that TOP2A protein was present in regions of cell division and that TOP2B protein was present in both proliferative and post mitotic areas.

TOP2 protein and activity levels were analysed in rat brain. TOP2A was present during embryogenesis and up to post-natal day 1 , whilst TOP2B was expressed at all ages [37]. TOP2 protein levels in murine tissues have been analysed by western blotting [38], whilst human TOP2 protein levels have been analysed by immunohistochemistry (see for example [39,40]). These studies showed TOP2A tightly associated with tissues containing proliferating cells whilst TOP2B is expressed more widely, including in post mitotic tissues. Transcriptome analysis of human tissues via the GTEx portal (www.gtexportal.org) reveals wide expression of TOP2B with highest expression in the cerebellum, while microarray analysis of TOP2B expression in primary human cells BioGPS.org) also demonstrates broad expression and highlights high expression in $\mathrm{CD}^{2} 4^{+}$bone marrow cells.

\section{TOP2B In Vivo Functions}

A type II topoisomerase is essential for mitosis. Both human isoforms can rescue yeast strains carrying a temperature sensitive mutation in top 2 [41,42]. However, in human cells the essential mitotic functions are carried out by TOP2A [43,44]. Murine embryos lacking Top2a terminated at the 4- or 8 -cell stage, confirming that mammalian cells require Top $2 a$ [45]. Mice lacking Top $2 b$ developed in utero, but the pups died shortly after birth due to lack of innervation of the diaphragm. Motor axons failed to contact the skeletal muscle and sensory axons failed to enter the spinal cord [46]. Conditional inactivation of Top $2 b$ in brain tissue using a conditional Cre-loxP system resulted in altered brain structures and abnormal cerebral lamination. Corticogenesis was adversely affected and neurons failed to migrate normally [47]. NURR1 (nuclear receptor related 1 protein) regulates expression of Top $2 b$; in Nurr 1 knockout mice Top $2 b$ is downregulated [21], suggesting Top $2 b$ is a downstream target of Nurr1. A number of studies have reported that TOP2 inhibitors reduce neurite formation, and isolated neurones from Top $2 b$ null embryos exhibit shorter neurites than controls [48,49]. Furthermore, genes regulated by TOP2B affect neuronal survival [50]. Since Top $2 b$ is regulated by NURR1 and NURR1 is known to be involved in the regulation of the dopaminergic system in the brain, TOP2B may have 
a role in axon genesis in dopaminergic neurons. A murine model in which Top $2 b$ was deleted from cardiomyocytes using a Cre-loxP showed protection from the cardio toxic effects of doxorubicin, confirming TOP2B plays a role in doxorubicin cardiotoxicity [51].

In zebrafish top $2 a$ is an essential gene [52]. Maternally encoded Top2a enables early development before the mid-zygotic transition, but transcription of top $2 a$ is required after this point, top $2 b$ cannot substitute $[53,54]$. A zebrafish screen to detect neurite patterning errors identified a top $2 b$ mutant (notorious, noto) with impaired neurite targeting to the inner plexiform layer. This affects axon guidance to the retina [55], further implicatingtop $2 b$ in neural development.

Non-replicating spermatids were shown to contain topoisomerase by Roca and Mezquita in 1989 [4], providing early evidence of a second type II topoisomerase. This study was ahead of its time, since more recently TOP2B has been demonstrated to have several important functions in sperm development. For example, TOP2B and PARP co-ordinate the chromatin reorganisation in developing spermatids when histone proteins are replaced by transition proteins and then by protamines [56-62].

\section{TOP2B as an Anti-Cancer Drug Target}

TOP2 carries out its strand passage activity by introducing a transient enzyme-bridged double-strand break in one DNA duplex segment through which a second segment is passed. Each protomer of the dimeric enzyme remains covalently linked to the $5^{\prime}$-end of the DSB via a phosphotyrosyl linkage during this process. The enzyme subsequently religates the break and is released. Human type II DNA topoisomerases are the molecular target for a number of drugs used in cancer chemotherapy. These drugs, referred to as TOP2 poisons, inhibit the religation step, and thus stabilise the normally transient enzyme-bridged DNA DSB that occurs during the TOP2 strand-passage reaction. These TOP2-DNA covalent complexes are cytotoxic and in sufficient quantity result in loss of cell viability. Clinically relevant TOP2 poisons include doxorubicin, epirubicin, daunorubicin, idarubicin, mitoxantrone, etoposide and mAMSA. There are extensive numbers of reviews on this topic, see, for example [63-65]. Interestingly, new combinations including these drugs are still being tested in clinical trials. For example, a recent trial found that mAMSA could reduce relapse incidence in AML-patients [66].

The discovery of TOP2B raised the question of whether TOP2A, TOP2B or both isoforms are targeted by different TOP2 poisons. However, a series of studies demonstrated that both TOP2B and TOP2A are targeted by TOP2 poisons. For example, in clongenic assays, murine embryo fibroblasts lacking Top $2 b$ were less sensitive to mAMSA than wild type cells and also demonstrated some resistance to mitoxantrone and etoposide [67]. This was confirmed in human cells lacking TOP2B, where TOP2B null cells showed the greatest resistance to mAMSA and mitoxantrone, and also showed resistance to etoposide and doxorubicin. Notably, in this study $T O P 2 B^{-/-}$null cells were significantly less sensitive to mAMSA and mitoxantrone than were TOP $2 A^{+/-}$heterozygotes, while for etoposide the TOP $2 A$, heterozygotes demonstrated the greatest resistance $[68,69]$. Further evidence for targeting of TOP2B by TOP2 poisons was provided using a yeast ts top2 system expressing functional human TOP2B. Human TOP2B complements the ts yeast top2 at the non-permissive temperature and this allows the selection of drug resistance mutants in the human enzyme in vivo. Nine mutated proteins were selected from a randomly mutated pool that conferred drug resistance to acridines, including $\mathrm{mAMSA}$, confirming TOP2B is a target for acridines [8,70-72].

Using an isoform-specific microscopy based immunoassay (trapped in agarose DNA immunostaining or TARDIS assay) $[73,74]$ to detect TOP2-DNA covalent complexes, we showed that etoposide induces complexes with both TOP2 isoforms, as does mAMSA and mitoxantrone [75-77]. The half-lives of the complexes in cells can be determined using the TARDIS assay. Etoposide-stabilised complexes have half-lives of $30 \mathrm{~min}$ for TOP2A and $15 \mathrm{~min}$ for TOP2B in human CCRF-CEM cells [76], whilst in MEFs the etoposide half-life for Top2a is $40 \mathrm{~min}$ and for Top2b is $20 \mathrm{~min}$. For mAMSA the half-life for both Top2a and Top2b is $15 \mathrm{~min}$ and mitoxantrone complexes are much longer lived, with a half-life of $10 \mathrm{~h}$ for Top2a and $6 \mathrm{~h}$ for Top2b [76]. The TARDIS assay is a microscopy-based method 
that allows the detection and quantification of TOP2-DNA covalent complex levels in individual cells. An alternative isoform specific assay is the ICE-assay, which involves ultra-centrifugation to separate the protein-DNA complexes followed by blotting the collected fractions on a slot blot and probing with isoform specific antibodies. This method also shows complexes with both TOP2 isoforms [68].

While they are effective and widely used anti-cancer agents, TOP2 poisons are also associated with therapy-related acute leukaemia, in particular acute myeloid leukaemia (t-AML) [78-80]. These t-AML cases often exhibit one of a set of recurrent chromosome translocations that drive the development of the leukaemia, most frequently involving the $M L L / K M T 2 A$ gene at 11q23, $\mathrm{t}(15,17)(P M L-R A R A)$, $\mathrm{t}(8,21)$ (RUNX1-ETO), or inv(16) (CBFB-MYH11) [79,81]. This raises the question of the relative contribution of TOP2A versus TOP2B in the aetiology of TOP2 poison-induced t-AML. While in principle either or both TOP2 isoforms could contribute to the induction of leukaemia-causing translocations via DNA cleavage at multiple loci followed by mis-repair, several lines of evidence point to TOP2B as the major contributor. For example, TOP2B is required for most etoposide-induced chromosome breaks at the MLL/KMT2A and RUNX1 loci using DNA FISH in a human cell line model $[82,83]$, top $2 b$ is required for efficient etoposide-induced recombination in a plasmid integration assay [84] and TOP2B is implicated in androgen-induced chromosome rearrangements in prostate cancer [85]. In addition, translocation partner genes such as KMT2A and AF9 or RUNX1 and ETO are closely juxtaposed in a fraction of cells, and this may be influenced by TOP2B $[82,83]$. This led to a model for the aetiology of TOP2 poison induced leukaemia where chromosome translocations are facilitated by co-localization of genes within common transcription factories, combined with TOP2B-mediated transcription-linked DNA breaks $[78,82,83,86]$. Furthermore, a proportion of TOP2B co-localises at conserved genomic locations with CTCF and members of the cohesin complex including RAD21 [87], presumably to resolve DNA topological problems. ChIP-seq combined with end-seq analysis demonstrated that this generates fragile sites in the genome that can contribute chromosome translocation [87-90]. Notably, t-AML patient associated MLL/KMT2A translocation breakpoints are enriched within a $1 \mathrm{~kb}$ region of intron 11 containing at one end a CTCF binding site [82,89].

\section{TOP2B Cell Biology-Cell Cycle Expression}

In contrast to its essential role in vertebrate development as observed in mice and zebrafish, in mammalian cell lines, TOP2B is not essential for cell viability [91,92]. There are cell cycle differences in TOP2A and TOP2B protein levels. In murine NIH-3T3 cells Top2a decreases 5.5 fold when cells plateau, whilst Top2b levels decrease by only 20\% [93]. NIH-3T3 cells were synchronised by serum starvation to analyse the effect of the cell cycle on Top2 protein levels; this demonstrated that Top2a was highest in $\mathrm{S}$ phase and G2/M and Top2b was present in all phases of the cell cycle [94]. Studies on five human leukaemia cell lines (K562, Raji, Molt 4, CCRF-CEM and Jurkat) determined that the two isoforms had differing salt extractabilities, and this was cell line dependent with the optimal level varying between 1 and $1.9 \mathrm{M}$ sodium chloride. The optimal salt extractability was as efficient as DNase I/RNase A digestion and SDS solubilisation [95]. TOP2 levels were quantified by western blotting with a standard curve of purified recombinant TOP2A or TOP2B and expressed as monomers per cell. Exponentially growing K562 cells contained 440,000 monomers of TOP2B and 570,000 monomers of TOP2A. Exponentially growing Raji cells were compared to confluent cultures. Exponentially growing cells contained 720,000 monomers of TOP2A and 1280,000 monomers of TOP2B. In contrast the confluent cells contained 300,000 monomers of TOP2B but only 60,000 monomers of TOP2A. In peripheral blood lymphocytes only TOP2B was detectable (290,000 monomers), consistent with differentiated cells lacking TOP2A, and in ALL patient blasts only TOP2B was detectable [95]. This is consistent with the majority of blasts being non-proliferating $[96,97]$.

Proliferation dependent topoisomerase II content has been reported to be a determinant of topoisomerase II mediated drug action, with topoisomerase levels being higher in log phase cells than in quiescent plateau phase cells from several species. These studies included cell lines derived 
from mice, Chinese hamster and human; cycling cells were more sensitive to drugs targeting DNA topoisomerase than quiescent plateau phase cells [98-102].

We present new data investigating drug targeting and cytotoxicity on rapidly proliferating K562 cells that have not been perturbed by serum starvation, separated by size using centrifugal elutriation. The buffer flow rate determines the size of cells eluted from the rotor. Cells are loaded into the chamber at low flow rate and as the flow rate is increased cells start to elute. Smallest cells (G1 phase cells) are eluted at lower flow rates than larger cells (G2/M phase cells); fractions collected at the different flow rates had different proportions of each cell cycle phase. As expected, the first fractions eluted were enriched for G1 cells compared to the starting cell population and contained fewer G2/M cells; the next fraction (17 mL/min) had more S-phase cells and fewer G2/M cells than the starting population, and the later fractions were enriched for G2/M cells, with few or no G1 cells. All the fractions contained S phase cells, but the percentage of S phase varied between $33 \%$ and $60 \%$, with $13 \mathrm{~mL} / \mathrm{min}$ having the lowest percentage of $\mathrm{S}$ phase cells and $20 \mathrm{~mL} / \mathrm{min}$ having the highest percentage of $S$ phase cells (Figure 2A).
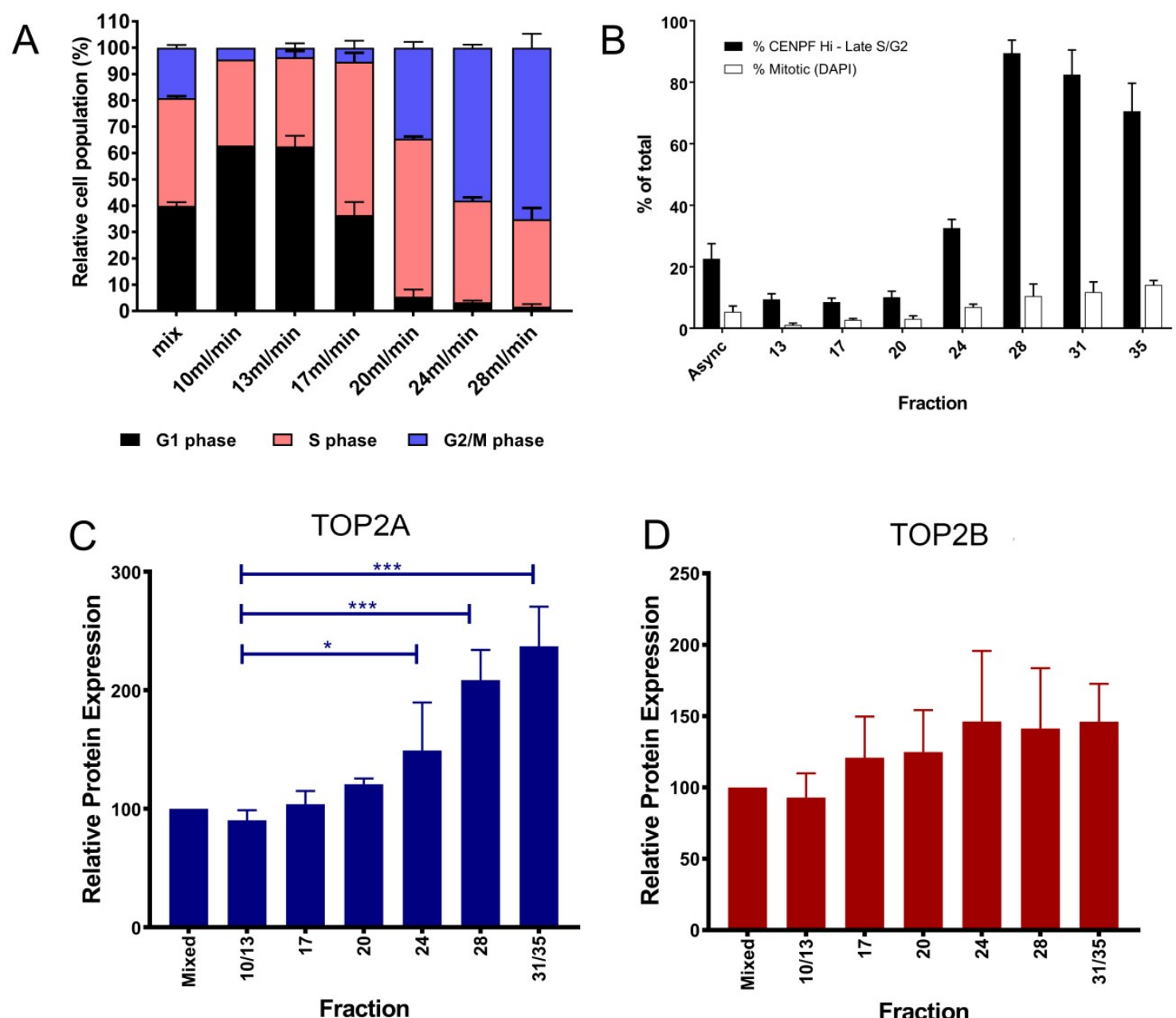

Figure 2. Elutriation of K562 cells separates the cells according to size. (A) FACS analysis (Flowjo) of each elutriation fraction showing the percentage of G1, S or G2/M phase cells. (B) Immunofluorescence analysis of each elutriation fraction showing the percentage of each fraction in lateS/G2/M determined by CENPF immunofluorescence and the percentage of mitotic cells determined by DAPI staining. (C,D) TOP2A and TOP2B protein level per cell was determined by quantitative immunofluorescence [77], the data shown represent the mean \pm SEM of median values obtained from three replicate experiments. Statistical analysis was carried out using one way ANOVA $\left({ }^{*} p<0.05 ; * * *<0.0001\right)$. 
The separated cells were then analysed in a range of ways. FACS analysis was used to determine DNA content, which is an indicator of cell cycle position, and also by immunofluorescence using two cell cycle markers (CENPF and H3Ser10P). G1 cells express low levels of CENPF and low phospho-H3Ser10, while late $S$ and G2/M cells contain increasing levels of CENPF, with highest levels in G2/M cells (Figure 2B), and condensing/condensed mitotic chromosomes are decorated with phospho-H3Ser10 [103,104]. TOP2A and TOP2B protein levels were determined on a single cell basis by quantitative immunofluorescence for each fraction. In K562 cells the levels of TOP2A increased significantly as the proportion of cells in $\mathrm{G} 2 / \mathrm{M}$ phase increased in fractions collected at 24,28 and $31 / 35 \mathrm{~mL} / \mathrm{min}$ (Figure $2 \mathrm{C}$ ) whilst TOP2B did not vary significantly between the fractions (Figure 2D). This is consistent with previous studies which showed TOP2A levels were highest in cells in $\mathrm{G} 2 / \mathrm{M}$ phase.

To determine if the K562 cell response to TOP2 drug targeting varied with cell cycle phase, we took the starting mixed culture and fractions collected at 10,13,17,20,24 $\mathrm{mL} / \mathrm{min}$ and treated them with the TOP2 targeting drug etoposide for one hour (it was not possible to test the $28 \mathrm{~mL} / \mathrm{min} \& 31 / 35$ $\mathrm{mL} / \mathrm{min}$ fractions as too few cells were present in these fractions). Using the trapped in agarose DNA immunostaining (TARDIS) method we were able to detect TOP2A and TOP2B covalent complexes in all the fractions following exposure to $100 \mu \mathrm{M}$ etoposide for one hour. For TOP2A, complexes were also efficiently formed in cells from each fraction following exposure to $10 \mu \mathrm{M}$ etoposide; for TOP2B $10 \mu \mathrm{M}$ etoposide resulted in a close to background signal for each fraction. An example of the data from a single elutriation experiment is shown in Figure 3A,B. Combined data from three independent elutriations revealed no significant difference in the formation of TOP2A or TOP2B complexes between the fractions or compared to the starting mixed population. To determine whether cell-cycle position affected etoposide-induced DSB formation, $\gamma \mathrm{H} 2 \mathrm{AX}$ quantitative immunofluorescence was used. $\gamma \mathrm{H} 2 \mathrm{AX}$ signal was seen in all fractions following exposure to 5,10 or $100 \mu \mathrm{M}$ etoposide for one hour, and the signal increased with etoposide concentration. Compared to the starting mixed population, two-way ANOVA of all three doses and all fractions tested indicted that the 10/13 mL fraction had lower levels of $\gamma \mathrm{H} 2 \mathrm{AX}$ integrated fluorescence. The 10/13 mL fraction contained fewer $\mathrm{S}$ phase cells than the starting population or the other four fractions tested and had the highest level of G1 cells (Figure 3C).

Cytotoxicity assays were carried out on the starting mixed population and on the 10, 13, 17, 20, $24 \mathrm{~mL} / \mathrm{min}$ fractions. Cells were treated for $1 \mathrm{~h}$ with etoposide and then placed in drug-free medium for 24,48 or $96 \mathrm{~h}$. Cell counts were analysed by population doubling. Etoposide concentrations of $0.5,5,10$ or $100 \mu \mathrm{M}$ were used. Figure 4 shows the population doubling 24,48 or $96 \mathrm{~h}$ after a $1-\mathrm{h}$ drug exposure. Population doubling was similar in the mixed population and all the fractions tested following exposure to $0.5 \mu \mathrm{M}$ etoposide for one hour followed by growth in drug free media. Indeed, after $0.5 \mu \mathrm{M}$ for $1 \mathrm{~h}$, there seemed little difference in population doubling compared to the untreated fractions. Following exposure to 10 or $100 \mu \mathrm{M}$ for one hour followed by growth in drug free media for 24 or $48 \mathrm{~h}$, the population doubling was noticeably reduced, in some cases dropping below 0 , indicating cytotoxicity and loss of cells. Compared to the starting mixed population the $\mathrm{G}_{1}$ /early S-enriched $17 \mathrm{~mL} / \mathrm{min}$ fraction was most affected. After $96 \mathrm{~h}$ in culture, there appeared little difference apart from fraction 17 that had been exposed to $100 \mu \mathrm{M}$ etoposide. 
A
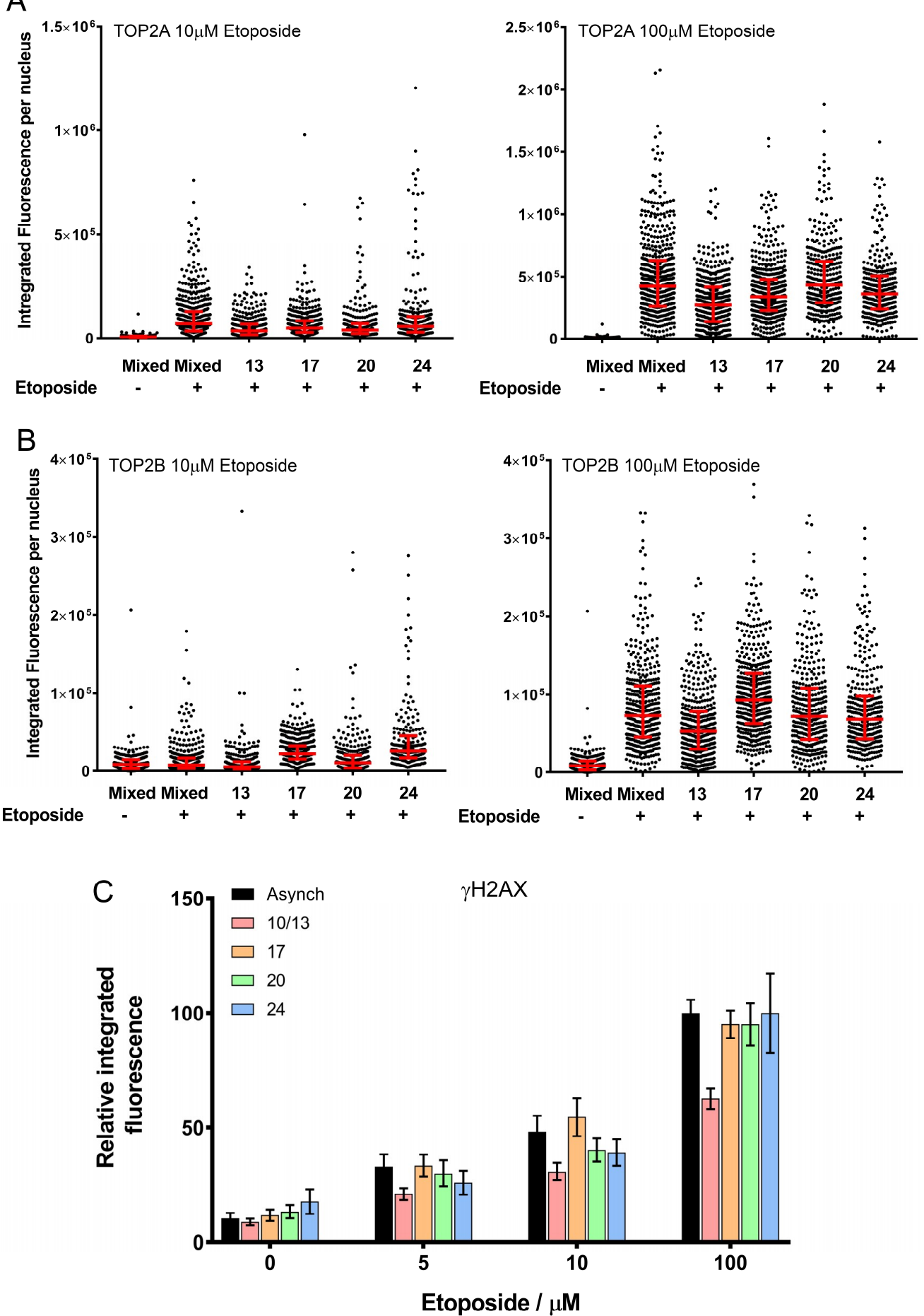

Figure 3. TOP2 covalent complex levels determined by trapped in agarose DNA immunostaining (TARDIS) and $\gamma \mathrm{H} 2 \mathrm{AX}$ integrated fluorescence. Quantification of etoposide-induced TOP2A and TOP2B covalent-DNA complexes, (A,B, respectively). Cells from each elutriated fraction were treated with etoposide $(10$ or $100 \mu \mathrm{M})$ and TOP2-DNA covalent complexes were detected and quantified by TARDIS analysis [73-75,77]. The data are shown as scattergrams, derived from a single representative experiment. Bars represent the median and interquartile range. (C) Cells from each elutriated fraction were treated with etoposide $(5,10$ or $100 \mu \mathrm{M})$ or solvent (DMSO) and analysed by $\gamma \mathrm{H} 2 \mathrm{AX}$ immunofluorescence; the level of $\gamma \mathrm{H} 2 \mathrm{AX}$ integrated fluorescence was determined by quantitative immunofluorescence [77]. The data are shown as means of the medians obtained from three replicate experiments. 

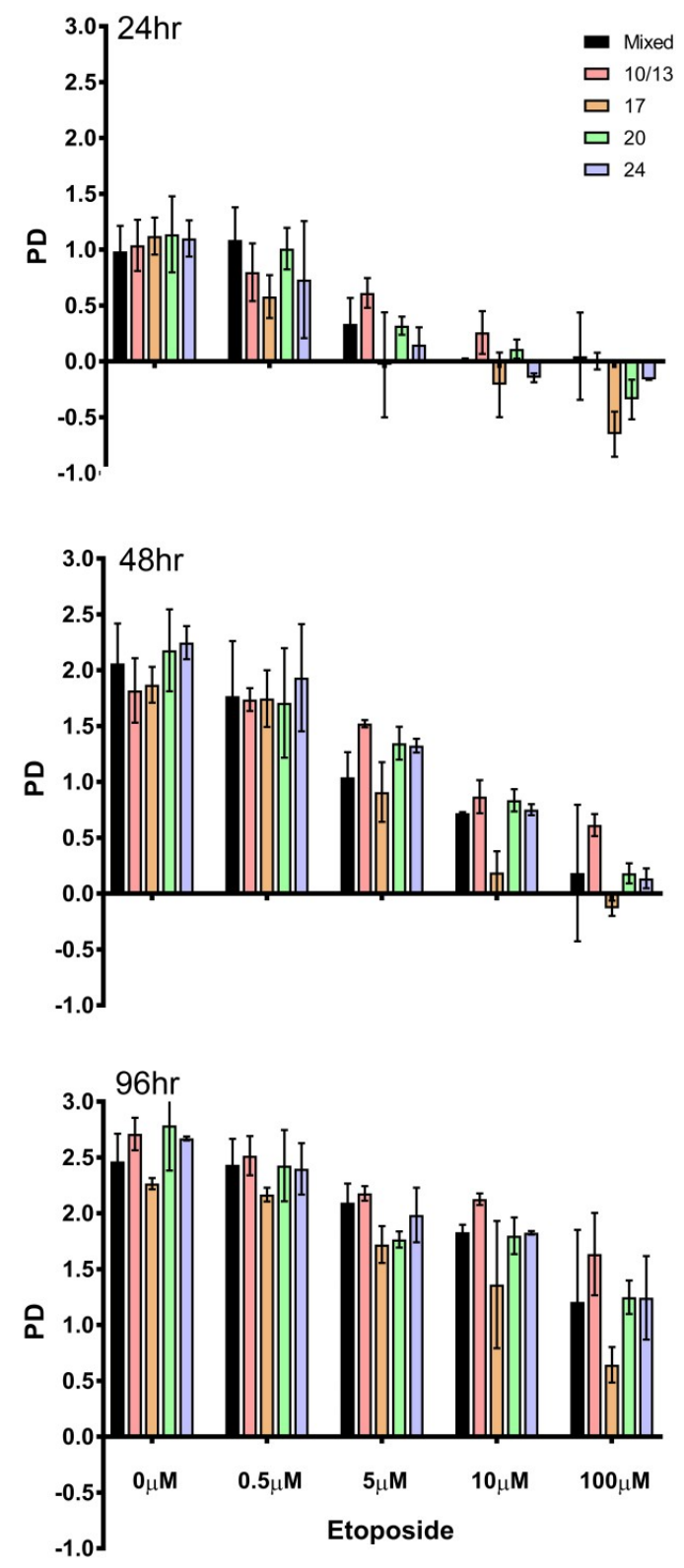

Figure 4. Drug sensitivity of the starting mixed population and the elutriated fractions. Cells from each elutriated fraction were treated with etoposide $(0-100 \mu \mathrm{M})$ for $1 \mathrm{~h}$. Cells were then replated in fresh medium and were counted after 24, 48 and $96 \mathrm{~h}$. Population doublings were calculated according to the formula PD $=\log _{10}$ (cell count/initial cell count) $/ \log _{10}$ (2). Data represent the mean \pm SEM derived from duplicate elutriation experiments.

In summary, for non-perturbed proliferating K562 cells separated into fractions based on size and cell cycle phase prior to exposure to etoposide for one hour, no differences in the level of topoisomerase II covalent complexes were seen in the different fractions (Figure 2A,B). Fluorescence intensity for gamma H2AX signal only differed in the $10 / 13 \mathrm{~mL} / \mathrm{min}$ fractions which contained the most $\mathrm{G} 1$ phase cells (Figure 2C). In these fractions the gamma H2AX signal was lower, suggesting fewer double strand breaks were formed when there were fewer $\mathrm{S}$ phase cells. Minimal difference in cytotoxicity was seen with $0.5 \mu \mathrm{M}$ etoposide when comparing the fractions with the starting population, but with higher concentrations the most sensitive fraction was that collected at $17 \mathrm{~mL} / \mathrm{min}$, containing early $\mathrm{S}$ phase cells. This indicates that early $S$ phase cells are more sensitive to etoposide, consistent with observations in previous studies in cells synchronised with serum starvation [98-102]. However, since the levels of TOP2-covalent complexes were similar in all fractions tested (Figure 2A,B), events downstream of 
complex formation, such as replication fork collision, may be responsible for the increased sensitivity to etoposide in early S phase cells, reviewed in Yan et al., 2016 [105].

\section{Subcellular Location of TOP2B Protein}

TOP2 is predominantly nuclear; the C-terminal domain of TOP2A and TOP2B contain nuclear localisation signals $[106,107]$ and both isoforms have nuclear export signals $[108,109]$. The interphase subcellular location of TOP2B has been the topic of a number of studies. Zini et al. reported that TOP2B was nucleolar [110], whilst another group found Top2b in both the nucleoplasm and nucleolus, and frequently associated with heterochromatin [111] and a third study suggested TOP2B was excluded from the nucleolus [112]. Chaly and Brown analysed the subcellular location of TOP2A and TOP2B under different fixation conditions with a number of antibodies. The conclusion of this study was that TOP2B was present largely in the nucleoplasm with some distribution in the nucleoli which was variable depending on antibody and fixation condition [113]. Studies with antisera raised to TOP2B CTD and using TOP2B CTD galactosidase tagged constructs in HeLa and monkey COS7 cells showed nucleoplasmic staining with no evidence for significant nucleolar enrichment [114]. Onoda et al., 2014 [115] show shuttling of TOP2B between the nucleolus and the nucleoplasm, and suggest that the enzyme is active when in the nucleoplasm. Cowell et al., 2011 demonstrated that Top $2 b$ is enriched in heterochromatic regions in mouse epithelial cells and relocates to give a pan nuclear staining upon treatment with the histone deacetylase inhibitor TSA [116], treatment which also causes loss of HP1 from heterochromatin [117]. Christensen et al., 2002, using photo bleaching, demonstrated that TOP2A and TOP2B were mobile within the nucleus [118]. Cell lysis conditions can affect the distribution of TOP2 in immunofluorescence localisation studies, and hypotonic cell lysis produced an axial pattern. During mitosis most TOP2B dissociates from chromatin, whilst most TOP2A remains chromosome bound $[112,119]$ and the mitotic functions of TOP2A cannot be carried out by TOP2B [43]. However, some studies also find TOP2B is associated with mitotic chromosomes [120,121]. In addition, two studies have indicated the presence of Top2b in mitochondria using mass spectroscopy, the first in 2003 [122] and the most recent in 2014 [123] where Top2a was also detected in mitochondria.

\section{Protein-Protein Interactions}

A wide range of approaches have been used to identify protein interaction partners of TOP2B. One of the first proteins identified as an interacting protein was CD3 epsilon; the cytoplasmic region of $\mathrm{CD} 3$ epsilon was used as bait to screen an expression library and it bound to the C-terminal domain of TOP2B [124]. The TOP2B interacting protein, DNA topoisomerase IIB binding protein one (TOPBP1) was identified in a yeast two hybrid screen with the C-terminal part of TOP2B (1143-1621) as bait [125]. UBC9, a SUMO1 conjugating enzyme, was identified as a TOP2B interacting partner via a 2 hybrid screen [126]. Phosphorylation of TOP2B by a range of kinases has been reported including CKII, PKC, PLK, Aurora B, cyclin B/cdc2 and MAPK [127-131]. Direct interaction with TOP2B has been reported for a number of kinases. TOP2B was pulled out when ERK1 was used as bait in a protein expression screen, clone S64 encoded residues 1398-1592 of TOP2B [132]. Using a combination of site directed mutagenesis and mass spectroscopy, three sites that could be phosphorylated in vitro by ERK1 were identified between residues 1398 and 1592: Serine 1419, Serine 1445 and Serine 1471 [133]. Other interacting kinases include Protein Kinase C C [134] and Casein Kinase II $\beta$ [135]. TOP2B has been shown to interact with tumour suppressor proteins p53 [136,137] and pRB [138,139]. To map the $\mathrm{pRB}$ interaction a yeast two hybrid system was used. This showed that the C-terminal domain of TOP2B interacted with the A box of pRB, and GST fusion protein pulldowns indicated the last 116 amino acid residues of TOP2B were sufficient for this interaction [139]. Histone deacetylates HDAC1 \& HDAC2 have also been shown to interact directly with TOP2B [140]. TOP2B has also been reported to be present within several complexes involved in ligand mediated transcriptional regulation, these include an RARB/TOP2B repressor complex [141], the Groucho/TLE1 repressor complex containing PARP and TOP2B [142] and a complex containing TOP2B, PARP, DNA-PK and 
KU antigen [143]. Wong et al., 2009 also found TOP2B to be a component of a transcriptional complex containing DNA-PK and KU antigen that is recruited to the fatty acid synthase (FAS) gene in response to insulin [144]. An interaction between KU and TOP2B was also reported by Matheos et al., 2002 [145]. Via programmes such as STRING (https://string-db.org/) [146] it is possible to view a range of interactions as they are reported.

Most recently, biotin ID mapping has been used to identify proteins interacting with TOP2B. A biotin ligase TOP2B fusion protein was expressed in HeLa cells and proteins in close proximity to TOP2B become biotinylated. They were then isolated on streptavidin beads and identified by mass spectrometry. This study reported 25 high confidence interacting partners for TOP2B (TOP2A, TOP1, CTCF, SMC1A, PDS5B, STAG1, STAG2, PDS5A, NIPBL, RAD21, HMGA1, YY1, ZNF451, ZNF512, ZNF362, DDX18, DDX31, PHF2, SDAD1, CBX8, LRIF1, HDGF, SRBD1, RRP15, MORC2) [87]. Interestingly recent mass spec analysis of the calf thymus protein purified in 1987 [147] confirmed the TOP2 purified from calf thymus contained both TOP2A and TOP2B and it co-purified with three proteins reported to interact with TOP2B via biotin ID mapping (TOP1, DDX18, SMC1A) [87] and with proteins reported to functionally interact with TOP2B such as PARP1.

\section{Transcriptional Roles of TOP2B}

DNA topoisomerases are required to relieve the topological stress during transcription, as detailed in the twin domain supercoiling model [148]. Both type II isoforms TOP2A and TOP2B have been reported to be involved in transcriptional regulation; Top2a appears to be required for gene regulation and priming in embryonic stem cells whilst a switch to Top2b occurs during differentiation $[50,149]$. TOP2B has been reported to mediate ligand-mediated transcription via a mechanism that introduces a double strand break $[85,141,143,150-152]$. A number of groups have reported TOP2B ChIP-seq studies, the first reported by Sano et al. in 2008, using rat cells [153]. More recent studies have reported ChIP-seq from human MCF7 cells [154], primary mouse B cells [89], mouse liver [87] and mouse brain [155,156]. Chip-seq analyses in humans [154] and mouse [87] identify transcription factor binding sites within the peak sequences associated with topoisomerase IIB; these included CTCF, SP1, EGR1, PAX5, and TFAP2. Furthermore, as described above, Uusküla-Reimand et al. [87] also showed that TOP2B is associated with CTCF and members of the cohesin complex at domain boundaries. In addition, Canela et al. [89] demonstrated that loop anchor regions bound by cohesin and CTCF are sensitive to etoposide-induced DSBs identified by end-seq; these breaks are co-incident with TOP2 ChIP peaks suggesting they are mediated by TOP2, probably TOP2B. This is consistent with a role for topoisomerases and transcription in mediating domains of supercoiling flanked by GC-AT boundaries and CTCF insulator protein-binding sites [157]. Topoisomerases have been reported to be particularly important for the transcription of long genes [158-160].

\section{Conclusions}

The first report of topoisomerase II $\beta$ protein was in 1987; that it was encoded by a separate gene was subsequently confirmed by cloning of the cDNA and mapping the gene location. Research in the first 10 years after TOP2B was reviewed in Austin and Marsh 1998 [29]. Subsequent research elucidated the biochemistry of this protein via site directed mutagenesis and crystallography of the enzyme core breakage reunion domain. Protein-protein interactions reveal that TOP2B interacts with various kinases responsible for phosphorylation; the cellular function of post translational modifications of TOP2B is an open question. TOP2B is associated with TOP2A in biotin ID mapping studies, raising the question of the presence and role of TOP2A/B heterodimers in cells. The murine knockout reported in 2000 demonstrated its importance for neural development. Studies more recently have demonstrated the importance of TOP2B in transcriptional regulation and genome organisation. Nevertheless, the detailed molecular mechanism of transcriptional regulation by TOP2B remains to be elucidated. A murine knockout in cardiomyocytes implicated TOP2B in cardiotoxicity [51]. TOP2B has also been implicated in the development of therapy related leukaemia $[78,82,83]$. The observations 
have led to the suggestion that drugs selectively targeting TOP2A may have clinical advantages; further work will be needed to determine if this is correct.

Author Contributions: Conceptualization, C.A.A. and I.G.C.; Methodology, C.A.A., I.G.C., R.L.S., M.M.K., K.C.L., C.M.M., P.C., A.T., A.P., N.J.M.; Formal Analysis, C.A.A., I.G.C., R.L.S., M.M.K., K.C.L., C.M.M., P.C., A.T., A.P., N.J.M.; Writing-Original Draft Preparation, C.A.A. and I.G.C.; Writing-Review \& Editing, C.A.A., I.G.C., R.L.S., C.M.M.

Funding: Research in our group has been funded by a wide range of funders including Bloodwise (R.L.S., K.C.L., I.G.C., C.A.A.) formerly Leukaemia and Lymphoma Research and the Leukaemia Research Fund, Grant reference numbers, Gordon Pillar Studentship 13063 (R.L.S.); Specialist Program Grant 12031 (K.C.L., I.G.C., C.A.A.); the BBSRC (C.M., P.C.) and Newcastle University (C.A.A. \& I.G.C.).

Acknowledgments: It has not been possible to cite every publication in the field and we apologise to all those whose work we could not cite here due to space limitations.

Conflicts of Interest: The authors declare no conflict of interest.

\section{Abbreviations}

$\begin{array}{ll}\text { CTCF } & \text { CCCTC-binding factor } \\ \text { CTD } & \text { C terminal domain } \\ \text { DSB } & \text { Double strand DNA break } \\ \text { t-AML } & \text { Therapy-related acute myeloid leukaemia } \\ \text { TARDIS } & \text { Trapped in agarose DNA immunostaining } \\ \text { TOP2A } & \text { DNA topoisomerase II } \alpha \\ \text { TOP2B } & \text { DNA topoisomerase II } \beta \\ \text { TOP2 } & \text { DNA topoisomerase II } \\ \text { ts } & \text { Temperature sensitive }\end{array}$

\section{References}

1. Drake, F.H.; Zimmerman, J.P.; McCabe, F.L.; Bartus, H.F.; Per, S.R.; Sullivan, D.M.; Ross, W.E.; Mattern, M.R.; Johnson, R.K.; Crooke, S.T. Purification of topoisomerase II from amsacrine-resistant P388 leukemia cells. Evidence for two forms of the enzyme. J. Biol. Chem. 1987, 262, 16739-16747. [PubMed]

2. Per, S.R.; Mattern, M.R.; Mirabelli, C.K.; Drake, F.H.; Johnson, R.K.; Crooke, S.T. Characterization of a subline of P388 leukemia resistant to amsacrine: Evidence of altered topoisomerase II function. Mol. Pharmacol. 1987, 32, 17-25. [PubMed]

3. Holden, J.A.; Rolfson, D.H.; Wittwer, C.T. Human DNA topoisomerase II: Evaluation of enzyme activity in normal and neoplastic tissues. Biochemistry 1990, 29, 2127-2134. [CrossRef] [PubMed]

4. Roca, J.; Mezquita, C. DNA topoisomerase II activity in nonreplicating, transcriptionally inactive, chicken late spermatids. EMBO J. 1989, 8, 1855-1860. [CrossRef] [PubMed]

5. Chung, T.D.; Drake, F.H.; Tan, K.B.; Per, S.R.; Crooke, S.T.; Mirabelli, C.K. Characterization and immunological identification of cDNA clones encoding two human DNA topoisomerase II isozymes. Proc. Natl. Acad. Sci. USA 1989, 86, 9431-9435. [CrossRef] [PubMed]

6. Tsai-Pflugfelder, M.; Liu, L.F.; Liu, A.A.; Tewey, K.M.; Whang-Peng, J.; Knutsen, T.; Huebner, K.; Croce, C.M.; Wang, J.C. Cloning and sequencing of cDNA encoding human DNA topoisomerase II and localization of the gene to chromosome region 17q21-22. Proc. Natl. Acad. Sci. USA 1988, 85, 7177-7181. [CrossRef] [PubMed]

7. West, K.L.; Meczes, E.L.; Thorn, R.; Turnbull, R.M.; Marshall, R.; Austin, C.A. Mutagenesis of E477 or K505 in the $\mathrm{B}^{\prime}$ domain of human topoisomerase II $\beta$ increases the requirement for magnesium ions during strand passage. Biochemistry 2000, 39, 1223-1233. [CrossRef] [PubMed]

8. Leontiou, C.; Watters, G.P.; Gilroy, K.L.; Heslop, P.; Cowell, I.G.; Craig, K.; Lightowlers, R.N.; Lakey, J.H.; Austin, C.A. Differential selection of acridine resistance mutations in human DNA topoisomerase II $\beta$ is dependent on the acridine structure. Mol. Pharmacol. 2007, 71, 1006-1014. [CrossRef] [PubMed]

9. Austin, C.A.; Marsh, K.L.; Wasserman, R.A.; Willmore, E.; Sayer, P.J.; Wang, J.C.; Fisher, L.M. Expression, domain structure, and enzymatic properties of an active recombinant human DNA topoisomerase II $\beta$. J. Biol. Chem. 1995, 270, 15739-15746. [CrossRef] [PubMed] 
10. Austin, C.A.; Fisher, L.M. Isolation and characterization of a human cDNA clone encoding a novel DNA topoisomerase II homologue from HeLa cells. FEBS Lett. 1990, 266, 115-117. [CrossRef]

11. Austin, C.A.; Sng, J.H.; Patel, S.; Fisher, L.M. Novel HeLa topoisomerase II is the II $\beta$ isoform: Complete coding sequence and homology with other type II topoisomerases. Biochim. Biophys. Acta 1993, 1172, $283-291$. [CrossRef]

12. Austin, C.A.; Barot, H.; Margerrison, E.E.C.; Hayes, M.V.; Fisher, L.M. Biochemical and immunological characterization of mammalian DNA topoisomerase II. Biochem. Soc. Trans. 1989, 17, 528-529. [CrossRef]

13. Tsutsui, K.; Okada, S.; Watanabe, M.; Shohmori, T.; Seki, S.; Inoue, Y. Molecular cloning of partial cDNAs for rat DNA topoisomerase II isoforms and their differential expression in brain development. J. Biol. Chem. 1993, 268, 19076-19083. [PubMed]

14. Jenkins, J.R.; Ayton, P.; Jones, T.; Davies, S.L.; Simmons, D.L.; Harris, A.L.; Sheer, D.; Hickson, I.D. Isolation of cDNA clones encoding the $\beta$ isozyme of human DNA topoisomerase II and localisation of the gene to chromosome 3p24. Nucleic Acids Res. 1992, 20, 5587-5592. [CrossRef] [PubMed]

15. Tan, K.B.; Dorman, T.E.; Falls, K.M.; Chung, T.D.; Mirabelli, C.K.; Crooke, S.T.; Mao, J. Topoisomerase II $\alpha$ and topoisomerase II $\beta$ genes: Characterization and mapping to human chromosomes 17 and 3, respectively. Cancer Res. 1992, 52, 231-234. [PubMed]

16. Lang, A.J.; Mirski, S.E.; Cummings, H.J.; Yu, Q.; Gerlach, J.H.; Cole, S.P. Structural organization of the human TOP2A and TOP2B genes. Gene 1998, 221, 255-266. [CrossRef]

17. Sng, J.H.; Heaton, V.J.; Bell, M.; Maini, P.; Austin, C.A.; Fisher, L.M. Molecular cloning and characterization of the human topoisomerase II $\alpha$ and II $\beta$ genes: Evidence for isoform evolution through gene duplication. Biochim. Biophys. Acta 1999, 1444, 395-406. [CrossRef]

18. Davies, S.L.; Jenkins, J.R.; Hickson, I.D. Human cells express two differentially spliced forms of topoisomerase II $\beta$ mRNA. Nucleic Acids Res. 1993, 21, 3719-3723. [CrossRef] [PubMed]

19. Ng, S.W.; Liu, Y.; Schnipper, L.E. Cloning and characterization of the 5 '-flanking sequence for the human DNA topoisomerase II $\beta$ gene. Gene 1997, 203, 113-119. [CrossRef]

20. Lok, C.-N.; Lang, A.J.; Mirski, S.E.L.; Cole, S.P.C. Characterization of the human topoisomerase II $\beta$ (TOP2B) promoter activity: Essential roles of the nuclear factor-Y (NF-Y)- and specificity protein-1 (Sp1)-binding sites. Biochem. J. 2002, 368, 741-751. [CrossRef] [PubMed]

21. Heng, X.; Jin, G.; Zhang, X.; Yang, D.; Zhu, M.; Fu, S.; Li, X.; Le, W. Nurr1 regulates Top II $\beta$ and functions in axon genesis of mesencephalic dopaminergic neurons. Mol. Neurodegen. 2012, 7, 4. [CrossRef] [PubMed]

22. Aravind, L.; Leipe, D.D.; Koonin, E.V. Toprim-A conserved catalytic domain in type IA and II topoisomerases, DnaG-type primases, OLD family nucleases and RecR proteins. Nucleic Acids Res. 1998, 26, 4205-4213. [CrossRef] [PubMed]

23. Wu, C.-C.; Li, T.-K.; Farh, L.; Lin, L.-Y.; Lin, T.-S.; Yu, Y.-J.; Yen, T.-J.; Chiang, C.-W.; Chan, N.-L. Structural basis of type II topoisomerase inhibition by the anticancer drug etoposide. Science 2011, 333, 459-462. [CrossRef] [PubMed]

24. Wendorff, T.J.; Schmidt, B.H.; Heslop, P.; Austin, C.A.; Berger, J.M. The structure of DNA-bound human topoisomerase II $\alpha$ : Conformational mechanisms for coordinating inter-subunit interactions with DNA cleavage. J. Mol. Biol. 2012, 424, 109-124. [CrossRef] [PubMed]

25. Berger, J.M.; Gamblin, S.J.; Harrison, S.C.; Wang, J.C. Structure and mechanism of DNA topoisomerase II. Nature 1996, 379, 225-232. [CrossRef] [PubMed]

26. Chen, S.H.; Chan, N.-L.; Hsieh, T. New Mechanistic and Functional Insights into DNA Topoisomerases. Annu. Rev. Biochem. 2013, 82, 139-170. [CrossRef] [PubMed]

27. Chang, C.-C.; Wang, Y.-R.; Chen, S.-F.; Wu, C.-C.; Chan, N.-L. New insights into DNA-binding by type IIA topoisomerases. Curr. Opin. Struct. Biol. 2013, 23, 125-133. [CrossRef] [PubMed]

28. Wei, H.; Ruthenburg, A.J.; Bechis, S.K.; Verdine, G.L. Nucleotide-dependent domain movement in the ATPase domain of a human type IIA DNA topoisomerase. J. Biol. Chem. 2005, 280, 37041-37047. [CrossRef] [PubMed]

29. Austin, C.A.; Marsh, K.L. Eukaryotic DNA topoisomerase II $\beta$. Bioessays 1998, 20, 215-226. [CrossRef]

30. Meczes, E.L.; Gilroy, K.L.; West, K.L.; Austin, C.A. The impact of the human DNA topoisomerase II C-terminal domain on activity. PLoS ONE 2008, 3, e1754. [CrossRef] [PubMed]

31. Gilroy, K.L.; Austin, C.A. The Impact of the C-Terminal Domain on the Interaction of Human DNA Topoisomerase II $\alpha$ and $\beta$ with DNA. PLoS ONE 2011, 6, e14693. [CrossRef] [PubMed] 
32. Linka, R.M.; Porter, A.C.G.; Volkov, A.; Mielke, C.; Boege, F.; Christensen, M.O. C-terminal regions of topoisomerase II $\alpha$ and II $\beta$ determine isoform-specific functioning of the enzymes in vivo. Nucleic Acids Res. 2007, 35, 3810-3822. [CrossRef] [PubMed]

33. Kozuki, T.; Chikamori, K.; Surleac, M.D.; Micluta, M.A.; Petrescu, A.J.; Norris, E.J.; Elson, P.; Hoeltge, G.A.; Grabowski, D.R.; Porter, A.C.G.; et al. Roles of the C-terminal domains of topoisomerase II $\alpha$ and topoisomerase II $\beta$ in regulation of the decatenation checkpoint. Nucleic Acids Res. 2017, 45, 5995-6010. [CrossRef] [PubMed]

34. Capranico, G.; Tinelli, S.; Austin, C.A.; Fisher, M.L.; Zunino, F. Different patterns of gene expression of topoisomerase II isoforms in differentiated tissues during murine development. Biochim. Biophys. Acta 1992, 1132, 43-48. [CrossRef]

35. Zandvliet, D.W.; Hanby, A.M.; Austin, C.A.; Marsh, K.L.; Clark, I.B.; Wright, N.A.; Poulsom, R. Analysis of foetal expression sites of human type II DNA topoisomerase $\alpha$ and $\beta$ mRNAs by in situ hybridisation. Biochim. Biophys. Acta 1996, 1307, 239-247. [CrossRef]

36. Harkin, L.F.; Gerrelli, D.; Gold Diaz, D.C.; Santos, C.; Alzu'bi, A.; Austin, C.A.; Clowry, G.J. Distinct expression patterns for type II topoisomerases IIA and IIB in the early foetal human telencephalon. J. Anat. 2016, 228, 452-463. [CrossRef] [PubMed]

37. Kondapi, A.K.; Mulpuri, N.; Mandraju, R.K.; Sasikaran, B.; Subba Rao, K. Analysis of age dependent changes of Topoisomerase II $\alpha$ and $\beta$ in rat brain. Int. J. Dev. Neurosci. 2004, 22, 19-30. [CrossRef] [PubMed]

38. Juenke, J.M.; Holden, J.A. The distribution of DNA topoisomerase II isoforms in differentiated adult mouse tissues. Biochim. Biophys. Acta 1993, 1216, 191-196. [CrossRef]

39. Bauman, M.E.; Holden, J.A.; Brown, K.A.; Harker, W.G.; Perkins, S.L. Differential immunohistochemical staining for DNA topoisomerase II $\alpha$ and $\beta$ in human tissues and for DNA topoisomerase II $\beta$ in non-Hodgkin's lymphomas. Mod. Pathol. 1997, 10, 168-175. [PubMed]

40. Turley, H.; Comley, M.; Houlbrook, S.; Nozaki, N.; Kikuchi, A.; Hickson, I.D.; Gatter, K.; Harris, A.L. The distribution and expression of the two isoforms of DNA topoisomerase II in normal and neoplastic human tissues. Br. J. Cancer 1997, 75, 1340-1346. [CrossRef] [PubMed]

41. Meczes, E.L.; Marsh, K.L.; Fisher, L.M.; Rogers, M.P.; Austin, C.A. Complementation of temperature-sensitive topoisomerase II mutations in Saccharomyces cerevisiae by a human TOP $2 \beta$ construct allows the study of topoisomerase II $\beta$ inhibitors in yeast. Cancer Chemother. Pharmacol. 1997, 39, 367-375. [CrossRef] [PubMed]

42. Jensen, S.; Redwood, C.S.; Jenkins, J.R.; Andersen, A.H.; Hickson, I.D. Human DNA topoisomerases $\mathrm{II} \alpha$ and II $\beta$ can functionally substitute for yeast TOP2 in chromosome segregation and recombination. Mol. Gen. Genet. 1996, 252, 79-86. [CrossRef] [PubMed]

43. Grue, P.; Grässer, A.; Sehested, M.; Jensen, P.B.; Uhse, A.; Straub, T.; Ness, W.; Boege, F. Essential mitotic functions of DNA topoisomerase II $\alpha$ are not adopted by topoisomerase II $\beta$ in human H69 cells. J. Biol. Chem. 1998, 273, 33660-33666. [CrossRef] [PubMed]

44. Gonzalez, R.E.; Lim, C.-U.; Cole, K.; Bianchini, C.H.; Schools, G.P.; Davis, B.E.; Wada, I.; Roninson, I.B.; Broude, E.V. Effects of conditional depletion of topoisomerase II on cell cycle progression in mammalian cells. Cell Cycle 2011, 10, 3505-3514. [CrossRef] [PubMed]

45. Akimitsu, N.; Adachi, N.; Hirai, H.; Hossain, M.S.; Hamamoto, H.; Kobayashi, M.; Aratani, Y.; Koyama, H.; Sekimizu, K. Enforced cytokinesis without complete nuclear division in embryonic cells depleting the activity of DNA topoisomerase II $\alpha$. Genes Cells 2003, 8, 393-402. [CrossRef] [PubMed]

46. Yang, X.; Li, W.; Prescott, E.D.; Burden, S.J.; Wang, J.C. DNA topoisomerase II $\beta$ and neural development. Science 2000, 287, 131-134. [CrossRef] [PubMed]

47. Lyu, Y.L.; Wang, J.C. Aberrant lamination in the cerebral cortex of mouse embryos lacking DNA topoisomerase IIß. Proc. Natl. Acad. Sci. USA 2003, 100, 7123-7128. [CrossRef] [PubMed]

48. Nur-E-Kamal, A.; Meiners, S.; Ahmed, I.; Azarova, A.; Lin, C.; Lyu, Y.L.; Liu, L.F. Role of DNA topoisomerase II $\beta$ in neurite outgrowth. Brain Res. 2007, 1154, 50-60. [CrossRef] [PubMed]

49. Zaim, M.; Isik, S. DNA topoisomerase II $\beta$ stimulates neurite outgrowth in neural differentiated human mesenchymal stem cells through regulation of Rho-GTPases (RhoA/Rock2 pathway) and Nurr1 expression. Stem Cell Res. Ther. 2018, 9, 114. [CrossRef] [PubMed] 
50. Tiwari, V.K.; Burger, L.; Nikoletopoulou, V.; Deogracias, R.; Thakurela, S.; Wirbelauer, C.; Kaut, J.; Terranova, R.; Hoerner, L.; Mielke, C.; et al. Target genes of Topoisomerase II $\beta$ regulate neuronal survival and are defined by their chromatin state. Proc. Natl. Acad. Sci. USA 2012, 109, E934-E943. [CrossRef] [PubMed]

51. Zhang, S.; Liu, X.; Bawa-Khalfe, T.; Lu, L.-S.; Lyu, Y.L.; Liu, L.F.; Yeh, E.T.H. Identification of the molecular basis of doxorubicin-induced cardiotoxicity. Nat. Med. 2012, 18, 1639-1642. [CrossRef] [PubMed]

52. Amsterdam, A.; Nissen, R.M.; Sun, Z.; Swindell, E.C.; Farrington, S.; Hopkins, N. Identification of 315 genes essential for early zebrafish development. Proc. Natl. Acad. Sci. USA 2004, 101, 12792-12797. [CrossRef] [PubMed]

53. Sapetto-Rebow, B.; McLoughlin, S.C.; O'Shea, L.C.; O’Leary, O.; Willer, J.R.; Alvarez, Y.; Collery, R.; O'Sullivan, J.; van Eeden, F.; Hensey, C.; et al. Maternal topoisomerase II $\alpha$, not topoisomerase II $\beta$, enables embryonic development of zebrafish top2a-/- mutants. BMC Dev. Biol. 2011, 11, 71. [CrossRef] [PubMed]

54. Dovey, M.; Patton, E.E.; Bowman, T.; North, T.; Goessling, W.; Zhou, Y.; Zon, L.I. Topoisomerase II $\alpha$ is required for embryonic development and liver regeneration in zebrafish. Mol. Cell. Biol. 2009, 29, 3746-3753. [CrossRef] [PubMed]

55. Nevin, L.M.; Xiao, T.; Staub, W.; Baier, H. Topoisomerase II $\beta$ is required for lamina-specific targeting of retinal ganglion cell axons and dendrites. Development 2011, 138, 2457-2465. [CrossRef] [PubMed]

56. Shaman, J.A.; Yamauchi, Y.; Ward, W.S. Sperm DNA fragmentation: Awakening the sleeping genome. Biochem. Soc. Trans. 2007, 35, 626-628. [CrossRef] [PubMed]

57. Leduc, F.; Maquennehan, V.; Nkoma, G.B.; Boissonneault, G. DNA damage response during chromatin remodeling in elongating spermatids of mice. Biol. Reprod. 2008, 78, 324-332. [CrossRef] [PubMed]

58. Meyer-Ficca, M.L.; Lonchar, J.D.; Ihara, M.; Meistrich, M.L.; Austin, C.A.; Meyer, R.G. Poly (ADP-Ribose) polymerases PARP1 and PARP2 modulate Topoisomerase II $\beta$ (TOP2B) function during chromatin condensation in mouse spermiogenesis. Biol. Reprod. 2011, 84, 900-909. [CrossRef] [PubMed]

59. Meyer, R.G.; Ketchum, C.C.; Meyer-Ficca, M.L. Heritable sperm chromatin epigenetics: A break to remember. Biol. Reprod. 2017, 97, 784-797. [CrossRef] [PubMed]

60. Ward, W.S. Regulating DNA supercoiling: Sperm points the way. Biol. Reprod. 2011, 84, 841-843. [CrossRef] [PubMed]

61. Ward, W.S. Organization of sperm DNA by the nuclear matrix. Am. J. Clin. Exp. Urol. 2018, 6, 87-92. [PubMed]

62. Güneş, S.; Kulaç, T. The role of epigenetics in spermatogenesis. Turk. J. Urol. 2013, 39, 181-187. [CrossRef] [PubMed]

63. Delgado, J.L.; Hsieh, C.-M.; Chan, N.-L.; Hiasa, H. Topoisomerases as anticancer targets. Biochem. J. 2018, 475, 373-398. [CrossRef] [PubMed]

64. Pommier, Y. Drugging topoisomerases: Lessons and challenges. ACS Chem. Biol. 2013, 8, 82-95. [CrossRef] [PubMed]

65. Nitiss, J.L. Targeting DNA topoisomerase II in cancer chemotherapy. Nat. Rev. Cancer 2009, 9, 338-350. [CrossRef] [PubMed]

66. Heinicke, T.; Labopin, M.; Schmid, C.; Polge, E.; Socié, G.; Blaise, D.; Mufti, G.J.; Huynh, A.; Brecht, A.; Ledoux, M.-P.; et al. Reduced relapse incidence with FLAMSA-RIC compared with busulfan/fludarabine for acute myelogenous leukemia patients in first or second complete remission: A study from the acute leukemia working party of the European Society for Blood and Marrow Transplantation. Biol. Blood Marrow Transplant. 2018. [CrossRef]

67. Errington, F.; Willmore, E.; Tilby, M.J.; Li, L.; Li, G.; Li, W.; Baguley, B.C.; Austin, C.A. Murine transgenic cells lacking DNA topoisomerase II $\beta$ are resistant to acridines and mitoxantrone: Analysis of cytotoxicity and cleavable complex formation. Mol. Pharmacol. 1999, 56, 1309-1316. [CrossRef] [PubMed]

68. Toyoda, E.; Kagaya, S.; Cowell, I.G.; Kurosawa, A.; Kamoshita, K.; Nishikawa, K.; Iiizumi, S.; Koyama, H.; Austin, C.A.; Adachi, N. NK314, a topoisomerase II inhibitor that specifically targets the $\alpha$ isoform. J. Biol. Chem. 2008, 283, 23711-23720. [CrossRef] [PubMed]

69. Lee, K.C.; Bramley, R.L.; Cowell, I.G.; Jackson, G.H.; Austin, C.A. Proteasomal inhibition potentiates drugs targeting DNA topoisomerase II. Biochem. Pharmacol. 2016. [CrossRef] [PubMed] 
70. Gilroy, K.L.; Leontiou, C.; Padget, K.; Lakey, J.H.; Austin, C.A. mAMSA resistant human topoisomerase II $\beta$ mutation G465D has reduced ATP hydrolysis activity. Nucleic Acids Res. 2006, 34, 1597-1607. [CrossRef] [PubMed]

71. Leontiou, C.; Lakey, J.H.; Austin, C.A. Mutation E522K in human DNA topoisomerase II $\beta$ confers resistance to methyl $N-\left(4^{\prime}-(9\right.$-acridinylamino)-phenyl) carbamate hydrochloride and methyl $N$-(4'-(9-acridinylamino)-3-methoxy-phenyl) methane sulfonamide but hypersensitivity to etoposide. Mol. Pharmacol. 2004, 66, 430-439. [PubMed]

72. Leontiou, C.; Lakey, J.H.; Lightowlers, R.; Turnbull, R.M.; Austin, C.A. Mutation P732L in human DNA topoisomerase II $\beta$ abolishes DNA cleavage in the presence of calcium and confers drug resistance. Mol. Pharmacol. 2006, 69, 130-139.

73. Cowell, I.G.; Tilby, M.J.; Austin, C.A. An overview of the visualisation and quantitation of low and high MW DNA adducts using the trapped in agarose DNA immunostaining (TARDIS) assay. Mutagenesis 2011, 26, 253-260. [CrossRef] [PubMed]

74. Cowell, I.G.; Austin, C.A. Visualization and Quantification of Topoisomerase-DNA Covalent Complexes Using the Trapped in Agarose Immunostaining (TARDIS) Assay. Methods Mol. Biol. 2018, 1703, 301-316. [CrossRef] [PubMed]

75. Willmore, E.; Frank, A.J.; Padget, K.; Tilby, M.J.; Austin, C.A. Etoposide targets topoisomerase II $\alpha$ and II $\beta$ in leukemic cells: Isoform-specific cleavable complexes visualized and quantified in situ by a novel immunofluorescence technique. Mol. Pharmacol. 1998, 54, 78-85. [CrossRef] [PubMed]

76. Errington, F.; Willmore, E.; Leontiou, C.; Tilby, M.J.; Austin, C.A. Differences in the longevity of topo II $\alpha$ and topo II $\beta$ drug-stabilized cleavable complexes and the relationship to drug sensitivity. Cancer Chemother. Pharmacol. 2004, 53, 155-162. [CrossRef] [PubMed]

77. Atwal, M.; Lishman, E.L.; Austin, C.A.; Cowell, I.G. Myeloperoxidase enhances etoposide and mitoxantrone mediated DNA damage: A target for myeloprotection in cancer chemotherapy. Mol. Pharmacol. 2017, 91, 49-57. [CrossRef] [PubMed]

78. Cowell, I.G.; Austin, C.A. Mechanism of generation of therapy related leukemia in response to anti-topoisomerase II agents. Int. J. Environ. Res. Public Health 2012, 9, 2075-2091. [CrossRef] [PubMed]

79. Rowley, J.D.; Olney, H.J. International workshop on the relationship of prior therapy to balanced chromosome aberrations in therapy-related myelodysplastic syndromes and acute leukemia: Overview report. Genes Chromosomes Cancer 2002, 33, 331-345. [CrossRef] [PubMed]

80. Allan, J.M.; Travis, L.B. Mechanisms of therapy-related carcinogenesis. Nat. Rev. Cancer 2005, 5, $943-955$. [CrossRef] [PubMed]

81. Felix, C.A. Secondary leukemias induced by topoisomerase-targeted drugs. Biochim. Biophys. Acta 1998, 1400, 233-255. [CrossRef]

82. Cowell, I.G.; Sondka, Z.; Smith, K.; Lee, K.C.; Manville, C.M.; Sidorczuk-Lesthuruge, M.; Rance, H.A.; Padget, K.; Jackson, G.H.; Adachi, N.; et al. Model for MLL translocations in therapy-related leukemia involving topoisomerase II $\beta$-mediated DNA strand breaks and gene proximity. Proc. Natl. Acad. Sci. USA 2012, 109, 8989-8994. [CrossRef] [PubMed]

83. Smith, K.A.; Cowell, I.G.; Zhang, Y.; Sondka, Z.; Austin, C.A. The role of topoisomerase II $\beta$ on breakage and proximity of RUNX1 to partner alleles RUNX1T1 and EVI1. Genes Chromosomes Cancer 2014, 53, 117-128. [CrossRef] [PubMed]

84. Azarova, A.M.; Lyu, Y.L.; Lin, C.-P.; Tsai, Y.-C.; Lau, J.Y.-N.; Wang, J.C.; Liu, L.F. Roles of DNA topoisomerase II isozymes in chemotherapy and secondary malignancies. Proc. Natl. Acad. Sci. USA 2007, 104, 11014-11019. [CrossRef] [PubMed]

85. Haffner, M.C.; Aryee, M.J.; Toubaji, A.; Esopi, D.M.; Albadine, R.; Gurel, B.; Isaacs, W.B.; Bova, G.S.; Liu, W.; Xu, J.; et al. Androgen-induced TOP2B-mediated double-strand breaks and prostate cancer gene rearrangements. Nat. Genet. 2010, 42, 668-675. [CrossRef] [PubMed]

86. Cowell, I.G.; Austin, C.A. Do transcription factories and TOP2B provide a recipe for chromosome translocations in therapy-related leukemia? Cell Cycle 2012, 11, 3143-3144. [CrossRef] [PubMed]

87. Uusküla-Reimand, L.; Hou, H.; Samavarchi-Tehrani, P.; Rudan, M.V.; Liang, M.; Medina-Rivera, A.; Mohammed, H.; Schmidt, D.; Schwalie, P.; Young, E.J.; et al. Topoisomerase II $\beta$ interacts with cohesin and CTCF at topological domain borders. Genome Biol. 2016, 17. [CrossRef] 
88. Vian, L.; Pękowska, A.; Rao, S.S.P.; Kieffer-Kwon, K.-R.; Jung, S.; Baranello, L.; Huang, S.-C.; El Khattabi, L.; Dose, M.; Pruett, N.; et al. The energetics and physiological impact of cohesin extrusion. Cell 2018, 173, 1165-1178. [CrossRef] [PubMed]

89. Canela, A.; Maman, Y.; Jung, S.; Wong, N.; Callen, E.; Day, A.; Kieffer-Kwon, K.-R.; Pekowska, A.; Zhang, H.; Rao, S.S.P.; et al. Genome organization drives chromosome fragility. Cell 2017, 170, 507-521. [CrossRef] [PubMed]

90. Rao, S.S.P.; Huang, S.-C.; Glenn St Hilaire, B.; Engreitz, J.M.; Perez, E.M.; Kieffer-Kwon, K.-R.; Sanborn, A.L.; Johnstone, S.E.; Bascom, G.D.; Bochkov, I.D.; et al. Cohesin loss eliminates all loop domains. Cell 2017, 171, 305-320. [CrossRef] [PubMed]

91. Dereuddre, S.; Delaporte, C.; Jacquemin-Sablon, A. Role of topoisomerase II $\beta$ in the resistance of 9-OH-ellipticine-resistant Chinese hamster fibroblasts to topoisomerase II inhibitors. Cancer Res. 1997, 57, 4301-4308. [PubMed]

92. Dereuddre, S.; Frey, S.; Delaporte, C.; Jacquemin-Sablon, A. Cloning and characterization of full-length cDNAs coding for the DNA topoisomerase II $\beta$ from Chinese hamster lung cells sensitive and resistant 9-OH-ellipticine. Biochim. Biophys. Acta 1995, 1264, 178-182. [CrossRef]

93. Woessner, R.D.; Chung, T.D.; Hofmann, G.A.; Mattern, M.R.; Mirabelli, C.K.; Drake, F.H.; Johnson, R.K. Differences between normal and ras-transformed NIH-3T3 cells in expression of the 170kD and 180kD forms of topoisomerase II. Cancer Res. 1990, 50, 2901-2908. [PubMed]

94. Woessner, R.D.; Mattern, M.R.; Mirabelli, C.K.; Johnson, R.K.; Drake, F.H. Proliferation-and cell cycle-dependent differences in expression of the 170 kilodalton and 180 kilodalton forms of topoisomerase II in NIH-3T3 cells. Cell Growth Differ. 1991, 2, 209-214. [PubMed]

95. Padget, K.; Pearson, A.D.; Austin, C.A. Quantitation of DNA topoisomerase II $\alpha$ and $\beta$ in human leukaemia cells by immunoblotting. Leukemia 2000, 14, 1997-2005. [CrossRef] [PubMed]

96. Oh, E.-J.; Kahng, J.; Kim, Y.; Kim, M.; Lim, J.; Kang, C.S.; Min, W.S.; Cho, B.; Lee, A.; Lee, K.Y.; et al. Expression of functional markers in acute lymphoblastic leukemia. Leuk. Res. 2003, 27, 903-908. [CrossRef]

97. Kaaijk, P.; Kaspers, G.J.L.; van Wering, E.R.; Broekema, G.J.; Loonen, A.H.; Hählen, K.; Schmiegelow, K.; Janka-Schaub, G.E.; Henze, G.; Creutzig, U.; et al. Cell proliferation is related to in vitro drug resistance in childhood acute leukaemia. Br. J. Cancer 2003, 88, 775-781. [CrossRef] [PubMed]

98. Sullivan, D.M.; Glisson, B.S.; Hodges, P.K.; Smallwood-Kentro, S.; Ross, W.E. Proliferation dependence of topoisomerase II mediated drug action. Biochemistry 1986, 25, 2248-2256. [CrossRef] [PubMed]

99. Sullivan, D.M.; Latham, M.D.; Ross, W.E. Proliferation-dependent topoisomerase II content as a determinant of antineoplastic drug action in human, mouse, and Chinese hamster ovary cells. Cancer Res. 1987, 47, 3973-3979. [PubMed]

100. Chow, K.C.; Ross, W.E. Topoisomerase-specific drug sensitivity in relation to cell cycle progression. Mol. Cell. Biol. 1987, 7, 3119-3123. [CrossRef] [PubMed]

101. Markovits, J.; Pommier, Y.; Kerrigan, D.; Covey, J.M.; Tilchen, E.J.; Kohn, K.W. Topoisomerase II-mediated DNA breaks and cytotoxicity in relation to cell proliferation and the cell cycle in NIH 3T3 fibroblasts and L1210 leukemia cells. Cancer Res. 1987, 47, 2050-2055. [PubMed]

102. Schneider, E.; Darkin, S.J.; Robbie, M.A.; Wilson, W.R.; Ralph, R.K. Mechanism of resistance of non-cycling mammalian cells to $4^{\prime}$-[9-acridinylamino]methanesulphon-m-anisidide: Role of DNA topoisomerase II in log- and plateau-phase CHO cells. Biochim. Biophys. Acta 1988, 949, 264-272. [CrossRef]

103. Cheung, P.; Allis, C.D.; Sassone-Corsi, P. Signaling to chromatin through histone modifications. Cell 2000, 103, 263-271. [CrossRef]

104. Liao, H.; Winkfein, R.J.; Mack, G.; Rattner, J.B.; Yen, T.J. CENP-F is a protein of the nuclear matrix that assembles onto kinetochores at late G2 and is rapidly degraded after mitosis. J. Cell Biol. 1995, 130, 507-518. [CrossRef] [PubMed]

105. Yan, H.; Tammaro, M.; Liao, S. Collision of trapped topoisomerase 2 with transcription and replication: Generation and repair of DNA double-strand breaks with $5^{\prime}$ adducts. Genes 2016, 7, 32. [CrossRef] [PubMed]

106. Adachi, N.; Miyaike, M.; Kato, S.; Kanamaru, R.; Koyama, H.; Kikuchi, A. Cellular distribution of mammalian DNA topoisomerase II is determined by its catalytically dispensable C-terminal domain. Nucleic Acids Res. 1997, 25, 3135-3142. [CrossRef] [PubMed]

107. Mirski, S.E.; Gerlach, J.H.; Cole, S.P. Sequence determinants of nuclear localization in the $\alpha$ and $\beta$ isoforms of human topoisomerase II. Exp. Cell Res. 1999, 251, 329-339. [CrossRef] [PubMed] 
108. Mirski, S.E.L.; Bielawski, J.C.; Cole, S.P.C. Identification of functional nuclear export sequences in human topoisomerase II $\alpha$ and $\beta$. Biochem. Biophys. Res. Commun. 2003, 306, 905-911. [CrossRef]

109. Turner, J.G.; Engel, R.; Derderian, J.A.; Jove, R.; Sullivan, D.M. Human topoisomerase II $\alpha$ nuclear export is mediated by two CRM-1-dependent nuclear export signals. J. Cell Sci. 2004, 117, 3061-3071. [CrossRef] [PubMed]

110. Zini, N.; Martelli, A.M.; Sabatelli, P.; Santi, S.; Negri, C.; Astaldi Ricotti, G.C.; Maraldi, N.M. The 180-kDa isoform of topoisomerase II is localized in the nucleolus and belongs to the structural elements of the nucleolar remnant. Exp. Cell Res. 1992, 200, 460-466. [CrossRef]

111. Petrov, P.; Drake, F.H.; Loranger, A.; Huang, W.; Hancock, R. Localization of DNA topoisomerase II in Chinese hamster fibroblasts by confocal and electron microscopy. Exp. Cell Res. 1993, 204, 73-81. [CrossRef] [PubMed]

112. Meyer, K.N.; Kjeldsen, E.; Straub, T.; Knudsen, B.R.; Hickson, I.D.; Kikuchi, A.; Kreipe, H.; Boege, F. Cell cycle-coupled relocation of types I and II topoisomerases and modulation of catalytic enzyme activities. J. Cell Biol. 1997, 136, 775-788. [CrossRef] [PubMed]

113. Chaly, N.; Brown, D.L. Is DNA topoisomerase II $\beta$ a nucleolar protein? J. Cell. Biochem. 1996, 63, $162-173$. [CrossRef]

114. Cowell, I.G.; Willmore, E.; Chalton, D.; Marsh, K.L.; Jazrawi, E.; Fisher, L.M.; Austin, C.A. Nuclear distribution of human DNA topoisomerase II $\beta$ : A nuclear targeting signal resides in the 116-residue C-terminal tail. Exp. Cell Res. 1998, 243, 232-240. [CrossRef] [PubMed]

115. Onoda, A.; Hosoya, O.; Sano, K.; Kiyama, K.; Kimura, H.; Kawano, S.; Furuta, R.; Miyaji, M.; Tsutsui, K.; Tsutsui, K.M. Nuclear dynamics of topoisomerase II $\beta$ reflects its catalytic activity that is regulated by binding of RNA to the C-terminal domain. Nucl. Acids Res. 2014, 42, 9005-9020. [CrossRef] [PubMed]

116. Cowell, I.G.; Papageorgiou, N.; Padget, K.; Watters, G.P.; Austin, C.A. Histone deacetylase inhibition redistributes topoisomerase II $\beta$ from heterochromatin to euchromatin. Nucleus 2011, 2, 61-71. [CrossRef] [PubMed]

117. Taddei, A.; Maison, C.; Roche, D.; Almouzni, G. Reversible disruption of pericentric heterochromatin and centromere function by inhibiting deacetylases. Nat. Cell Biol. 2001, 3, 114-120. [CrossRef] [PubMed]

118. Christensen, M.O.; Larsen, M.K.; Barthelmes, H.U.; Hock, R.; Andersen, C.L.; Kjeldsen, E.; Knudsen, B.R.; Westergaard, O.; Boege, F.; Mielke, C. Dynamics of human DNA topoisomerases II $\alpha$ and II $\beta$ in living cells. J. Cell Biol. 2002, 157, 31-44. [CrossRef] [PubMed]

119. Chaly, N.; Chen, X.; Dentry, J.; Brown, D.L. Organization of DNA topoisomerase II isotypes during the cell cycle of human lymphocytes and HeLa cells. Chromosome Res. 1996, 4, 457-466. [CrossRef] [PubMed]

120. Taagepera, S.; Rao, P.N.; Drake, F.H.; Gorbsky, G.J. DNA topoisomerase II $\alpha$ is the major chromosome protein recognized by the mitotic phosphoprotein antibody MPM-2. Proc. Natl. Acad. Sci. USA 1993, 90, 8407-8411. [CrossRef] [PubMed]

121. Null, A.P.; Hudson, J.; Gorbsky, G.J. Both $\alpha$ and $\beta$ isoforms of mammalian DNA topoisomerase II associate with chromosomes in mitosis. Cell Growth Differ. 2002, 13, 325-333. [PubMed]

122. Low, R.L.; Orton, S.; Friedman, D.B. A truncated form of DNA topoisomerase II $\beta$ associates with the mtDNA genome in mammalian mitochondria. Eur. J. Biochem. 2003, 270, 4173-4186. [CrossRef] [PubMed]

123. Zhang, H.; Zhang, Y.-W.; Yasukawa, T.; Dalla Rosa, I.; Khiati, S.; Pommier, Y. Increased negative supercoiling of mtDNA in TOP1mt knockout mice and presence of topoisomerases II $\alpha$ and II $\beta$ in vertebrate mitochondria. Nucleic Acids Res. 2014, 42, 7259-7267. [CrossRef] [PubMed]

124. Nakano, H.; Yamazaki, T.; Miyatake, S.; Nozaki, N.; Kikuchi, A.; Saito, T. Specific interaction of topoisomerase $\mathrm{II} \beta$ and the CD3 $\varepsilon$ chain of the T cell receptor complex. J. Biol. Chem. 1996, 271, 6483-6489. [CrossRef] [PubMed]

125. Yamane, K.; Kawabata, M.; Tsuruo, T. A DNA-topoisomerase-II-binding protein with eight repeating regions similar to DNA-repair enzymes and to a cell-cycle regulator. Eur. J. Biochem. 1997, 250, 794-799. [CrossRef] [PubMed]

126. Mao, Y.; Desai, S.D.; Liu, L.F. SUMO-1 conjugation to human DNA topoisomerase II isozymes. J. Biol. Chem. 2000, 275, 26066-26073. [CrossRef] [PubMed]

127. Wells, N.J.; Hickson, I.D. Human topoisomerase II $\alpha$ is phosphorylated in a cell-cycle phase-dependent manner by a proline-directed kinase. Eur. J. Biochem. 1995, 231, 491-497. [CrossRef] [PubMed] 
128. Wells, N.J.; Fry, A.M.; Guano, F.; Norbury, C.; Hickson, I.D. Cell cycle phase-specific phosphorylation of human topoisomerase II $\alpha$. Evidence of a role for protein kinase C. J. Biol. Chem. 1995, 270, 28357-28363. [PubMed]

129. Morrison, C.; Henzing, A.J.; Jensen, O.N.; Osheroff, N.; Dodson, H.; Kandels-Lewis, S.E.; Adams, R.R.; Earnshaw, W.C. Proteomic analysis of human metaphase chromosomes reveals topoisomerase II $\alpha$ as an Aurora B substrate. Nucleic Acids Res. 2002, 30, 5318-5327. [CrossRef] [PubMed]

130. Cardenas, M.E.; Gasser, S.M. Regulation of topoisomerase II by phosphorylation: A role for casein kinase II. J. Cell Sci. 1993, 104, 219-225. [PubMed]

131. Olsen, J.V.; Blagoev, B.; Gnad, F.; Macek, B.; Kumar, C.; Mortensen, P.; Mann, M. Global, in vivo, and site-specific phosphorylation dynamics in signaling networks. Cell 2006, 127, 635-648. [CrossRef] [PubMed]

132. Fukunaga, R.; Hunter, T. MNK1, a new MAP kinase-activated protein kinase, isolated by a novel expression screening method for identifying protein kinase substrates. EMBO J. 1997, 16, 1921-1933. [CrossRef] [PubMed]

133. Manville, C.M. Kinase Associated Genotoxicity. Ph.D. Thesis, Newcastle University, Newcastle upon Tyne, UK, 2012.

134. Plo, I.; Hernandez, H.; Kohlhagen, G.; Lautier, D.; Pommier, Y.; Laurent, G. Overexpression of the atypical protein kinase $\mathrm{C}$ zeta reduces topoisomerase II catalytic activity, cleavable complexes formation, and drug-induced cytotoxicity in monocytic U937 leukemia cells. J. Biol. Chem. 2002, 277, 31407-31415. [CrossRef] [PubMed]

135. Ahn, B.H.; Kim, T.H.; Bae, Y.S. Mapping of the interaction domain of the protein kinase CKII $\beta$ subunit with target proteins. Mol. Cells 2001, 12, 158-163. [PubMed]

136. Cowell, I.G.; Okorokov, A.L.; Cutts, S.A.; Padget, K.; Bell, M.; Milner, J.; Austin, C.A. Human topoisomerase $\mathrm{II} \alpha$ and II $\beta$ interact with the C-terminal region of p53. Exp. Cell Res. 2000, 255, 86-94. [CrossRef] [PubMed]

137. Yuwen, H.; Hsia, C.C.; Nakashima, Y.; Evangelista, A.; Tabor, E. Binding of wild-type p53 by topoisomerase II and overexpression of topoisomerase II in human hepatocellular carcinoma. Biochem. Biophys. Res. Commun. 1997, 234, 194-197. [CrossRef] [PubMed]

138. Xiao, H.; Goodrich, D.W. The retinoblastoma tumor suppressor protein is required for efficient processing and repair of trapped topoisomerase II-DNA-cleavable complexes. Oncogene 2005, 24, 8105-8113. [CrossRef] [PubMed]

139. Cridland, P. (Newcastle University, Newcastle upon Tyne, UK). Personal communication, 2018.

140. Tsai, S.C.; Valkov, N.; Yang, W.M.; Gump, J.; Sullivan, D.; Seto, E. Histone deacetylase interacts directly with DNA topoisomerase II. Nat. Genet. 2000, 26, 349-353. [CrossRef] [PubMed]

141. McNamara, S.; Wang, H.; Hanna, N.; Miller, W.H. Topoisomerase II $\beta$ negatively modulates retinoic acid receptora function: A novel mechanism of retinoic acid resistance. Mol. Cell. Biol. 2008, 28, 2066-2077. [CrossRef] [PubMed]

142. Ju, B.-G.; Solum, D.; Song, E.J.; Lee, K.-J.; Rose, D.W.; Glass, C.K.; Rosenfeld, M.G. Activating the PARP-1 Sensor Component of the Groucho/TLE1 Corepressor Complex Mediates a CaMKinase II $\delta$-Dependent Neurogenic Gene Activation Pathway. Cell 2004, 119, 815-829. [CrossRef] [PubMed]

143. Ju, B.G.; Lunyak, V.V.; Perissi, V.; Garcia-Bassets, I.; Rose, D.W.; Glass, C.K.; Rosenfeld, M.G. A topoisomerase II $\beta$-mediated dsDNA break required for regulated transcription. Science 2006, 312, 1798-1802. [CrossRef] [PubMed]

144. Wong, R.H.F.; Chang, I.; Hudak, C.S.S.; Hyun, S.; Kwan, H.-Y.; Sul, H.S. A Role of DNA-PK for the Metabolic Gene Regulation in Response to Insulin. Cell 2009, 136, 1056-1072. [CrossRef] [PubMed]

145. Matheos, D.; Ruiz, M.T.; Price, G.B.; Zannis-Hadjopoulos, M. Ku antigen, an origin-specific binding protein that associates with replication proteins, is required for mammalian DNA replication. Biochim. Biophys. Acta 2002, 1578, 59-72. [CrossRef]

146. Szklarczyk, D.; Morris, J.H.; Cook, H.; Kuhn, M.; Wyder, S.; Simonovic, M.; Santos, A.; Doncheva, N.T.; Roth, A.; Bork, P.; et al. The STRING database in 2017: Quality-controlled protein-protein association networks, made broadly accessible. Nucleic Acids Res. 2017, 45, D362-D368. [CrossRef] [PubMed]

147. Austin, C.A.; Barot, H.A.; Margerrison, E.E.; Turcatti, G.; Wingfield, P.; Hayes, M.V.; Fisher, L.M. Structure and partial amino acid sequence of calf thymus DNA topoisomerase II: Comparison with other type II enzymes. Biochem. Biophys. Res. Commun. 1990, 170, 763-768. [CrossRef] 
148. Liu, L.F.; Wang, J.C. Supercoiling of the DNA template during transcription. Proc. Natl. Acad. Sci. USA 1987, 84, 7024-7027. [CrossRef] [PubMed]

149. Thakurela, S.; Garding, A.; Jung, J.; Schübeler, D.; Burger, L.; Tiwari, V.K. Gene regulation and priming by topoisomerase II $\alpha$ in embryonic stem cells. Nat. Commun. 2013, 4. [CrossRef] [PubMed]

150. Perillo, B.; Ombra, M.N.; Bertoni, A.; Cuozzo, C.; Sacchetti, S.; Sasso, A.; Chiariotti, L.; Malorni, A.; Abbondanza, C.; Avvedimento, E.V. DNA oxidation as triggered by H3K9me2 demethylation drives estrogen-induced gene expression. Science 2008, 319, 202-206. [CrossRef] [PubMed]

151. McNamara, S.; Nichol, J.N.; Wang, H.; Miller, W.H. Targeting PKC $\delta$-mediated topoisomerase II $\beta$ overexpression subverts the differentiation block in a retinoic acid-resistant APL cell line. Leukemia 2010, 24, 729-739. [CrossRef] [PubMed]

152. Puc, J.; Aggarwal, A.K.; Rosenfeld, M.G. Physiological functions of programmed DNA breaks in signal-induced transcription. Nat. Rev. Mol. Cell Biol. 2017, 18, 471. [CrossRef] [PubMed]

153. Sano, K.; Miyaji-Yamaguchi, M.; Tsutsui, K.M.; Tsutsui, K. Topoisomerase II $\beta$ activates a subset of neuronal genes that are repressed in AT-rich genomic environment. PLoS ONE 2008, 3, e4103. [CrossRef] [PubMed]

154. Manville, C.M.; Smith, K.; Sondka, Z.; Rance, H.; Cockell, S.; Cowell, I.G.; Lee, K.C.; Morris, N.J.; Padget, K.; Jackson, G.H.; et al. Genome-wide ChIP-seq analysis of human TOP2B occupancy in MCF7 breast cancer epithelial cells. Biol. Open 2015. [CrossRef] [PubMed]

155. Feng, W.; Kawauchi, D.; Körkel-Qu, H.; Deng, H.; Serger, E.; Sieber, L.; Lieberman, J.A.; Jimeno-González, S.; Lambo, S.; Hanna, B.S.; et al. Chd7 is indispensable for mammalian brain development through activation of a neuronal differentiation programme. Nat. Commun. 2017, 8, 14758. [CrossRef] [PubMed]

156. Madabhushi, R.; Gao, F.; Pfenning, A.R.; Pan, L.; Yamakawa, S.; Seo, J.; Rueda, R.; Phan, T.X.; Yamakawa, H.; Pao, P.-C.; et al. Activity-induced DNA breaks govern the expression of neuronal early-response genes. Cell 2015, 161, 1592-1605. [CrossRef] [PubMed]

157. Naughton, C.; Avlonitis, N.; Corless, S.; Prendergast, J.G.; Mati, I.K.; Eijk, P.P.; Cockroft, S.L.; Bradley, M.; Ylstra, B.; Gilbert, N. Transcription forms and remodels supercoiling domains unfolding large-scale chromatin structures. Nat. Struct. Mol. Biol. 2013, 20, 387-395. [CrossRef] [PubMed]

158. King, I.F.; Yandava, C.N.; Mabb, A.M.; Hsiao, J.S.; Huang, H.-S.; Pearson, B.L.; Calabrese, J.M.; Starmer, J.; Parker, J.S.; Magnuson, T.; et al. Topoisomerases facilitate transcription of long genes linked to autism. Nature 2013, 501, 58-62. [CrossRef] [PubMed]

159. Joshi, R.S.; Piña, B.; Roca, J. Topoisomerase II is required for the production of long Pol II gene transcripts in yeast. Nucl. Acids Res. 2012, 40, 7907-7915. [CrossRef] [PubMed]

160. Joshi, R.S.; Nikolaou, C.; Roca, J. Structure and Chromosomal Organization of Yeast Genes Regulated by Topoisomerase II. Int. J. Mol. Sci. 2018, 19, 134. [CrossRef] [PubMed] 